https://doi.org/10.5194/bg-2021-1

Preprint. Discussion started: 1 February 2021

(C) Author(s) 2021. CC BY 4.0 License.

(c) (i)

\title{
Experimental production of charcoal morphologies to discriminate fuel source and fire type in the Siberian taiga
}

Angelica Feurdean ${ }^{1}$

${ }^{1}$ Department of Physical Geography, Goethe University, Altenhöferallee 1, 60438 Frankfurt am Main, Germany

5 Correspondence to: angelica.feurdean@gmail.com; Feurdean@em.uni-frankfurt.de

\begin{abstract}
The analysis of charcoal fragments in peat and lake sediments is the most widely used approach to reconstruct past biomass burning. With a few exceptions, this method typically relies on the quantification of the total charcoal content of the sediment. To enhance charcoal analyses for the reconstruction of past fire regimes, and to make the method more relevant to

10 studies of both plant evolution and fire management, more information must be extracted from charcoal particles. Here, I burned in the laboratory seven fuel types comprising 17 species from boreal Siberia, and build on published schemes to develop morphometric and finer diagnostic classifications of the experimentally charred particles. As most of the species used in this study are common to Northern Hemisphere forests and peatlands, these results can be directly applicable over a broad geographical scale. Results show that the effect of temperature on charcoal production is fuel dependent. Graminoids and

15 Sphagnum, and wood (trunk) lose the most mass at low burn temperatures, whereas heathland shrub leaves, brown moss, and ferns retain the most mass at high burn temperatures. In contrast to the wood of trunk, the wood of twigs retained their mass at intermediate temperature. This suggests that species with low mass retention at hotter burning temperatures might be underrepresented in the fossil charcoal record. Charred particle aspect ratio $(L / W)$ appeared to be the strongest indicator of the fuel type burnt. Graminoid charcoals are more elongate than those of all other fuel types, leaf charcoals are the shortest and

20 bulkiest, and twig and wood charcoals are intermediate. Finer diagnostic features were the most useful in distinguishing between wood, graminoid, and leaf particles, but further distinctions within these fuel types are difficult. High-aspect-ratio particles dominated by graminoid and Sphagnum morphologies are robust indicators of cooler surface fires. Contrastingly, abundant wood and leaf morphologies and low-aspect-ratio particles likely indicate higher-temperature fires. However, the overlapping morphologies of leaves and wood from trees and shrubs make it hard to distinguish between high-intensity surface
\end{abstract}

25 fires combusting living shrubs and dead wood and leaves or high-intensity crown fires combusting living trees. Despite these limitations, the combined use of charred-particle aspect ratios and fuel morphotypes can aid in more robustly interpreting changes in fuel source and fire type, thereby substantially refining histories of past wildfires. Further fields of investigation to improve the interpretation of the fossil charcoal records will require: i) More in-depth knowledge of plant anatomy for a better determination of fuel sources; ii) Relate the proportion of particular charcoal morphotypes to the quantity of biomass; iii) Link

30 the chemical composition of fuels, combustion temperature, and charcoal production. The advanced use of image-recognition software to collect data on other charcoal features could also aid in extracting fire temperatures as well as a change in particles morphology and morphometry during particles transportation. 
https://doi.org/10.5194/bg-2021-1

Preprint. Discussion started: 1 February 2021

(c) Author(s) 2021. CC BY 4.0 License.

\section{Introduction}

Boreal forests are among the ecosystems most significantly impacted by wildfires as a consequence of climate change (Jones et al., 2020). Although most of the global boreal forest area is in Siberia (Furayev, 1996), its vast extent and restricted access have limited datasets recording changes in wildfire activity, especially from a longer-term perspective (Marlon et al., 2016. Such long-term records of wildfire activity are vital to understanding how fire regimes vary with changes in climate and

40 human-vegetation interaction, as well as the impacts of fires on boreal forests.

Charcoal is an inorganic carbon compound resulting from the incomplete combustion of plant tissues, which typically occurs at temperatures of $280-500{ }^{\circ} \mathrm{C}$ (Rein, 2014). Charcoal particles vary in size and form, but can preserve characteristics such as edge aspects, surface features, cleavage, lustre, or anatomical details (tracheids with border pits, leaf veins, cuticles, etc.) that can be used to determine the origin of the fuel (Ward and Hardy, 1991; MacDonald et al., 1991; Scott 2010; Enache and

45 Cumming, 2006; Jensen et al., 2007; Courtney-Mustaphi and Pisaric, 2014). Although macroscopic charcoal analysis, typically counting charcoal pieces or charcoal area per unit sediment volume, is widely applied, the full potential of this method has not been explored. This analytical limitation restricts the reconstruction of fuel sources, a crucial factor in determining fire type, i.e., the burning of surface fuels in cool or hot fires, or distinguishing between surface and crown fires, which requires greater distinction of fuel types (Courtney-Mustaphi and Pisaric, 2014; Feurdean et al., 2017; Hawthorne et al., 2018). Furthermore,

50 the determination of fire type is not only critical to palaeofire reconstructions, but it is an accessible tool for ecosystem managers and modellers, and for assessing and mitigating the risks of fires that might impact settlements and infrastructures (Moritz et al., 2014).

Ongoing efforts have advanced the utility of charcoal analyses for fuel type identification and fire regime reconstruction. Umbanhowar and McGrath (1998) and Pereboom et al. (2020) conducted morphometric measurements of the length, aspect

55 ratio (length/width), and surface area of charcoal particles by burning in the laboratory known plant materials originating from American prairie and arctic environments, and concluded that longer (higher aspect ratio) fragments correspond to graminoids, whereas shorter fragments originate from wood, shrubs, and leaves. Other studies have focused on the effects of burning conditions, i.e., open-flame ignition, muffle furnace experiments, and combustion calorimetry on charcoal production (Umbanhowar and McGrath, 1998; Orvis et al., 2005; Hudspith et al., 2018). Jensen et al. (2005) and Courtney-Mustaphi and

60 Pisaric (2014) investigated subtler diagnostic features (morphology, surface features, lustre) of laboratory-produced charcoal morphotypes of a small number of North American grasses and leaves of coniferous and deciduous trees. Furthermore, Enache and Cumming (2006, 2007) and Mustaphi and Pisaric (2014) classified charcoal morphologies in Canadian lake sediments based on particle shape (morphology), aspect ratio, and surface features, and linked them to fuel types. Based on published morphotype categorisations, more recent studies have attributed fossil charred particles to certain fuel and fire types (Walsh et

65 al., 2010, Daniau et al., 2013; Aleman et al., 2013; Courtney-Mustaphi and Pisaric, 2014; Feurdean et al., 2017, 2019a, 2019b, 2020; Unkelbach et al., 2018). 
https://doi.org/10.5194/bg-2021-1

Preprint. Discussion started: 1 February 2021

(C) Author(s) 2021. CC BY 4.0 License.

(c) (i)

This paper presents the first results of laboratory-produced charcoal morphologies spanning a range of fuel types originating from 17 boreal Siberian species. It aims is to facilitate more robust interpretations of fuel sources and fire types, which will substantially refine wildfire histories in boreal forests. Specifically, it tested (i) whether morphological distinctions exist between species and fuel types, and (ii) the effect of burning temperature on the mass, morphometrics, and finer anatomical features of charred plant material. The papers also discuss the advantages and limitations of laboratory-based burning studies for palaeofire reconstruction. Because this combination of factors has never been tested to such an extent in the laboratory, this study has the potential to significantly advance our understanding of the link between sedimentary charcoal morphologies and fire types. As most of the species used in this study are common to Northern Hemisphere forests and peatlands, these results are directly applicable over a broad geographical scale.

\section{Material and Methods}

\subsection{Laboratory analysis}

Plant materials were identified in the field, stored in plastic bags for transportation, and air-dried to complete dryness. Selected materials include a range of fuel types (graminoid, trunk wood, twigs of tree and shrub, and the leaves of coniferous and deciduous trees, shrubs, forbs, and ferns, moss, and fern stems with leaves) from the most common tree, shrub, herb, fern, and moss species around a forested bog near Teguldet village, Tomsk district, Russia. This light boreal taiga forest is primarily composed of Pinus and Betula. Additionally, needles and twigs of Picea abies were collected from Taunus, near Frankfurt am Main, Germany (see Table 1 for a full list of species and fuel types).

85 This paper builds on previous morphological classifications of charcoal particles and tested the effects of increasing burning temperatures on the mass, morphometrics, and finer diagnostic features of residual charred remains of various fuel types as follows. Dried remains of individual plant species were placed in ceramic crucibles, weighed, covered with a lid to limit oxygen availability, and heated for $2 \mathrm{~h}$ in a muffle oven (preheated for $1 \mathrm{~h}$ ) at 250,300,350,400, or $450{ }^{\circ} \mathrm{C}$. No burning experiments were conducted at higher temperatures because all plant material turned to ash at $450{ }^{\circ} \mathrm{C}$ under these conditions. The

90 experimental temperatures were chosen based on the range of temperatures reported in the literature $\left(250-500{ }^{\circ} \mathrm{C}\right.$; Umbanhower and McGrath, 1998; Orvis et al., 2005; Jensen et al., 2007; Peereboom et al., 2020). It also tested the effect of mixing plant material in known ratios on charred mass and morphometrics at $300{ }^{\circ} \mathrm{C}$, an intermediate temperature. For this, the plant material was combined in the following volume: $25 \%$ graminoid and moss, $75 \%$ shrub; $50 \%$ graminoid, shrub, and moss, 50\% wood and leaf; 50\% graminoid and moss, 50\% shrub; 75\% graminoid, shrub, and moss, 25\% wood and leaf; $75 \%$

95 graminoid and moss, 25\% shrub; and 50\% graminoid, 50\% moss and fern. These samples represent the predominant fuel mixtures of cold surface fires (graminoid and moss), intermediate- to high-intensity surface fires (shrub), and high-intensity crown fires (wood and tree leaf).

The influence of increasing burn temperature on the mass of residual charred plant material was determined to establish whether different fuel types produced different amounts of charcoal. After cooling each sample, the remaining charred mass was weighed and calculated the ratio of charred to pre-combustion mass. 
https://doi.org/10.5194/bg-2021-1

Preprint. Discussion started: 1 February 2021

(C) Author(s) 2021. CC BY 4.0 License.

Charred samples were then split into two subsets. The first was left intact and stored as reference material. The second was gently disaggregated with a mortar and pestle to mimic the natural breakage that charcoal particles would incur overtime in sediment (Crawford and Belcher, 2014; Umbanhowar and McGrath, 1998), then washed through a 125- $\mu \mathrm{m}$ sieve to remove smaller fragments. This second sample split was subjected to both morphometric measurements and characterization of finer diagnostic features. Morphometric measurements of individual charred particles were obtained from photographs taken at $4 \times$ magnification with a digital camera (Kern DXM 1200F). Between 100 and 300 charcoal particles larger than $150 \mu \mathrm{m}$ were automatically detected in most samples and the measurement of the major $(L)$ and minor $(W)$ axes, and surface area $(A)$ of each particle following the algorithm presented in Appendix A1, the calculated aspect ratio as $L / W$. These measurements were performed for all experiments producing residual charred material (i.e., below $450^{\circ} \mathrm{C}$ ). Finer diagnostic features such as shape,

110 surface features (reticulates, tracheids with border pits, leaf veins, the arrangement of epidermal cells, cuticles with stomata, etc), and cleavage were characterized at $4 \times$ by inspection of microphotographs or the charred particles themselves under a microscope or stereomicroscope.

\subsection{Numerical analysis}

The medians and standard deviations of charcoal morphometrics $(L, L / W, A)$ were aggregated for each species, fuel type, and

115 burn temperature, and are displayed as box plots. The two-tailed Mann-Whitney test was used to test whether the medians of the charcoal morphometrics of various fuel types were equal. This test does not assume a normal distribution, only equallyshaped distributions in both groups.

\section{Results}

\section{$120 \quad 3.1$ The influence of temperature on charred mass production}

Only a few fuel types (needles, shrub leaves) were partly charred after burning at $250{ }^{\circ} \mathrm{C}$ and were greenish or brownish in colour. Plant materials of all species were black with a typical charcoal appearance after burning at 300 and $350{ }^{\circ} \mathrm{C}$. A few fuel types (graminoid, Sphagnum, and some twigs) became fully carbonised (ash) at $400{ }^{\circ} \mathrm{C}$, and all others were only partly carbonised. All plant tissue was reduced to ash at $450^{\circ} \mathrm{C}$ (Fig. S1). The majority of the charred materials remained intact and retained all their morphological characteristics. However, those burnt at higher temperatures tended to easily break during sample manipulation.

The percentage of charred mass retained at $300{ }^{\circ} \mathrm{C}$ (an intermediate temperature) was as follows, in decreasing order: brown moss and fern $>$ twig $($ shrub $)>$ leaf $($ shrub $)>$ leaf (forb) $>$ leaf (coniferous tree) $>$ twig (tree) $>$ needles $>$ graminoid $>$ Sphagnum $>$ wood (trunk) (Fig. 1). This mass-loss trend was largely the same at all temperatures. Trunk wood, graminoids, and Sphagnum

130 lost most of their mass at lower temperatures (up to $350^{\circ} \mathrm{C}$ ), whereas leaves of shrub, forbs, and ferns retained the most charred mass at $400{ }^{\circ} \mathrm{C}$. The charred mass of mixed-fuel samples at $300{ }^{\circ} \mathrm{C}$ reflected the dominant fuel type; it was lowest for samples with high contents of graminoid and Sphagnum and highest for samples with greater proportions of the shrub. 
https://doi.org/10.5194/bg-2021-1

Preprint. Discussion started: 1 February 2021

(C) Author(s) 2021. CC BY 4.0 License.

(c) (i)

\subsection{Fuel-dependent variations in length, aspect ratio, and surface area}

135 Graminoid charcoals burnt at $300{ }^{\circ} \mathrm{C}(L / W=9.1$, Fig. $2 \mathrm{~b}, \mathrm{f})$ were consistently more elongate than those of twigs (shrub, 4.6 ; tree, 3.1), moss and fern stems (3.7), and leaves (2.1). Among leaves, charred needles were more elongate (2.7) than those of forb (2), heathland shrub (1.94), and broadleaf tree leaves (1.84). The Mann-Whitney test confirmed that (i) the median aspect ratio of graminoids was significantly different from those of all other fuel types $(p<0.001)$, (ii) those of woods (all types) were different from those of leaves $(p<0.001)$ and moss (except at $350{ }^{\circ} \mathrm{C}$ ) and (iii) those of leaves were different from those

140 of moss $(p<0.001$; Table 2). The size distribution of charred particles indicates that the smaller fractions tend to be rounder (lower aspect ratio) than the larger fractions (not shown). In contrast to the median aspect ratio, the lengths (major axis, $L$ ) of charred particles from different fuel types were less clearly differentiated (Figs. 3a, c, S2; Table 2). The surface area (A) varied greatly between individual taxa and fuel types, however, fragments of shrub leaves tended to be larger than all other fuel types (Figs. 3b, d, S3; Table 2).

145 The aspect ratios and lengths of individual taxa and fuel types changed slightly with temperature, but the general trends were similar across all temperatures (Figs. 2, 3a, c, S2). In contrast, relative surface areas varied more with temperature changes (Figs. 3b, d, S3).

The morphometrics of mixed-fuel samples reflected those of the dominant fuel types: charcoals of samples with abundant graminoids and moss were more elongate (higher $L / W$ ) than those with higher proportions of shrubs, wood, and/or leaves (Fig.

150 2h). Similarly, the longest charcoal particles (higher $L$ ) were from samples with greater proportions of graminoids and moss (Fig. 3e), whereas the charcoals with the largest surface areas were from samples with more abundant shrubs and leaves (Fig. 3f).

\subsection{Finer diagnostic features of the charcoal morphologies of various fuel types}

\section{3.3.1 Graminoid charcoal}

Graminoid (Carex, Calamagrostis, E. vaginatum) charred particles were consistently flat, rectangular, and elongated (Figs. 4a, A2a). They mostly broke parallel to the long axis when pressured, resulting in highly elongated pieces with straight margins. They can also appear as featureless long, thin filaments. Charcoals produced at higher temperatures $\left(350{ }^{\circ} \mathrm{C}\right)$ often had more irregular, zig-zag, or denticulate margins. Their surface features more commonly preserved rectangular epidermal cells or contained oval voids, reticulated or mesh patterns, and/or isolated veins.

\subsubsection{Wood charcoal (trunk, tree and shrub twigs)}

Wood charcoal pieces from trunk (P. sylvestris) were blocky and quadrilateral with corner angles of $90^{\circ}$ (Figs. 4b, A2b). Wood charcoal from tree (P. sylvestris, P. sibirica, Picea abies, B. pendula) and shrub (Ericaceae) twigs showed both quadrilateral

165 and polygonal shapes. For both trunks and twigs, edges were smooth, serrated, or denticulate, and surface textures were smooth, foliated, or striated (Fig. 4b). Trunk charcoals of $P$. sylvestris showed rows of brown, open pits in the tracheid walls. 
https://doi.org/10.5194/bg-2021-1

Preprint. Discussion started: 1 February 2021

(C) Author(s) 2021. CC BY 4.0 License.

(c) (i)

Under the microscope, trunk charcoal fragments were shinier and darker than twig charcoals. Large charcoal pieces often broke parallel to the long axis, producing many tiny, elongated pieces (trunks) or pieces of various forms (twigs).

\subsubsection{Leaf charcoal (needles, deciduous tree and shrub, forb, and fern)}

Charred needle fragments were elongated and rectangular (corner angles of $90^{\circ}$; Figs. 4c, A2a). Their edges were smooth, but became serrated and denticulate when broken. Surface features included visible venation and ridges. Charcoals from the leaves of deciduous trees (Betula), heathland shrubs (Oxyccocum, Ledum, Camadaphne, Vaccinium), herbaceous plants (Rubus), and ferns (Polypodicacea) were polygonal. Only those of Cnidium leaves were elongated, reflecting their needle shape. Edges were mostly undulate, but sometimes smooth or denticulate. Surface textures were generally smooth (featureless), but sometimes included visible venation and ridges. When broken, they showed voids, reticulated mesh patterns, and curly fibres. Birch leaves produced visible charred veins with three branches diverging from a node. When pressured and broken, small leaf pieces had fracture lines radiating out at a variety of angles.

\section{3.3.4 Moss and fern stems}

Sphagnum produced two types of charcoal morphologies. One type originates from stems were elongate with ramifications (scars) where leaves branched from the stem, and the other originates from leaves preserved the anatomical features of the unburned leaves, i.e., a mesh-like appearance (Figs. 4a, A2a). Politrichum produced several charcoal morphologies (quadrilateral, polygonal, or curved with angular edges) with generally featureless surfaces, although some showed mesh

185 patterns. This charcoal type often splits along the main axis. Equisetum stems were generally quadrilateral with straight, undulate, or denticulate margins, and oval voids and reticulated mesh patterns on their surfaces.

\section{Discussion}

Results from laboratory-produced charred morphologies evaluate the morphometrical aspects, fine diagnostic features, and

190 charcoal production for 17 plant species and seven fuel types from boreal Siberia. This dataset substantially broadens the geographical cover of fuel types researched and improves the interpretation of fire types based on charcoal morphologies.

\subsection{The influence of combustion temperature on charred mass production: implications for charcoal-based fire reconstructions}

195 Knowledge of the charred mass is critical for determining biases in charcoal production to biomass quantity and fire temperature (Walsh and Li, 1964). Results from this study clearly show that the effect of temperature on charcoal production is fuel dependent. When averaged across all temperatures, graminoid, Sphagnum, and trunk wood produce the lowest amounts of charcoal per unit biomass, whereas leaves of shrubs (Ericaceae), forbs, and ferns (Polypodiaceae), as well as fern stems (Equisetum), produced the highest (Fig. 1). The charred mass of mixed-fuel samples also changed according to the dominant 200 fuel type (at $300{ }^{\circ} \mathrm{C}$ ). Peerboom et al. (2020) burned plant tissue from the Alaskan tundra at $500{ }^{\circ} \mathrm{C}$, and similarly found that 
https://doi.org/10.5194/bg-2021-1

Preprint. Discussion started: 1 February 2021

(c) Author(s) 2021. CC BY 4.0 License.

(c) (i)

graminoids have lower charred-mass retention than shrubs. However, they neither tested leaves and wood of shrubs separately, nor the effect of various temperatures on charred mass. In my experiments, the charred mass of graminoid and Sphagnum declined quickly with increasing burn temperature, whereas the leaves of shrubs and forbs and the stems of ferns and brown moss retained the most charred mass at higher temperatures; twigs were intermediate (Fig. 1). Note, however, that the trunk wood used in the current experiments was collected from a dead trunk, and may have burned faster than wood from living trees. In partial agreement with findings from this study, burning experiments of American forest steppe plants showed that the mass retention of grass and deciduous leaf charcoal decrease more rapidly with temperature compared to wood charcoal (Umbanhower and McGrath, 1998). More recent calorimetric combustion of various fuel types found the charr mass of wood, needles and Equisetum to be higher than other leaf types, mostly originating from tropical species (Hudspith et al., 2017).

210 The burn conditions in the experiments (oxygen level, temperature, fuel moisture and arrangement, etc.) do not fully replicate those of natural wildfires. Nonetheless, these findings present some practical implications for charcoal-based fire reconstructions. First, fuel types with low charred-mass retention at hotter burn temperatures might be underrepresented in the sedimentary charcoal record. Specifically, Cyperaceae (sedges) are the most common graminoids in fens and meso- and eutrophic bogs, and Eriophorum (sedge) and Sphagnum (moss) are common in oligotrophic bogs. These fuel types are likely to be the first to turn to ash, even in relatively cool fires, and thus may leave little or no trace of charcoal in sediments. Second, Ericaceae (heathland shrubs), typical of oligotrophic bogs, and Polytrichum commune (brown moss) common to all habitat types, have a high charred-mass retention until $300{ }^{\circ} \mathrm{C}$ (woody biomass). However, their masses decline strongly at higher temperatures $\left(350-400{ }^{\circ} \mathrm{C}\right)$, indicating that they are likely to be preserved as charcoal only in low- to intermediate-intensity fires. Third, leaves of shrub, forb, and fern, and stems with leaves of Equisetum are more likely to persist as charcoal after high-temperature fires, and thus may contribute excessively to sedimentary charcoal. Mineral constituents can slow the pyrolysis, and this is probably why Equisetum steams with high silica content, preserve more charcoal. Fuel with higher lignin content (wood) should also produce more charcoal than fuels higher in cellulose and hemicellulose i.e., leaves (Yang et al., 2007). Contrasted to this expectation, leaves in the present laboratory experiments, retained a higher charred mass than the wood with increasing burn temperature, which calls into extending such research to fuels with various chemical proprieties.

\subsection{Fuel-dependent variability in morphometrics: implications for fuel-type reconstructions}

Some of the charred fragments produced herein show consistent morphometrics among species within the same genus and family, suggesting their utility for fuel-type identification. Graminoid charcoal particles are at least two times more elongated than all other charcoal types and differ the most from leaf charcoals (Fig. 2). Highly elongate and narrow graminoid charcoals

230 are posited to result from the occurrence of conspicuous veins parallel to the long axis (Umbanhowar and McGrath, 1998). Charred fragments of forb and shrub leaves are also markedly rounder than those of other fuel types, but there is some degree of overlap between the aspect ratios of the remaining fuel types. In practice, this translates to a high degree of confidence in using aspect ratio in identifying sedimentary charcoals of graminoids, including those typical of wetlands, and most leaf types (Fig. 2). Charcoal fragments from mixed-fuel samples also preserve the aspect ratio of the dominant fuel type; the longest 
https://doi.org/10.5194/bg-2021-1

Preprint. Discussion started: 1 February 2021

(c) Author(s) 2021. CC BY 4.0 License.

(c) (i)

235 particles were found in samples with higher proportions of graminoids. Because smaller charred fractions tend to be rounder (lower aspect ratio) than larger fractions, it suggests that larger charcoal fragments can be more confidently used to morphometrically categorise fuel types. Results also show that changes in the length of fuel types are largely similar to changes in aspect ratio. However, length alone provides a less clear distinction between fuel types (Figs. 3, S2). In contrast, there is little confidence in using the mean surface area to distinguish between fuel types, except for the slightly tendency that charred shrub leaf particles are larger than those of all other fuel types (Figs. 3, S3). The larger shrub leaf fragments may be explained by the arrangement of leaf venation, with fragments breaking along the three branching veins that diverge from nodes (Umbanhowar and McGrath, 1998; Jenssen et al., 2007). The shape of charcoal particles also affects their transport, with elongate particles transported over shorter distances than round ones (Clark and Hussey, 1996; Higuera et al., 2014). This implies that graminoid, moss, and fern charcoals may be deposited closer to the origin of fire than the rounder, polygonal leaf

\section{5 particles.}

The morphometrics of graminoids and forb and shrub leaves observed herein are most similar to those from the Alaskan arctic (Pereboom et al., 2020), but significantly more elongate (9.1) than those from American steppe forests (3.62; Umbanhowar and McGrath, 1998) and tropical African forests and grasslands (>2.0; Aleman et al., 2013). Mustaphy and Pisaric (2014) also observed that burning monocotyledons from boreal Canada in the laboratory generally produced more elongated charcoal

250 morphologies than other fuels (deciduous leaves, needles, wood, rootlets).

Results from measurements of the effect of temperature on charred-particle morphometrics show that the aspect ratio is generally preserved for all fuel types over the temperatures explored. However, the length and surface area of fuel types changed less consistently with increasing temperature. Umbanhowar and McGrath, (1998) found that burn temperature did not significantly change the aspect ratios of graminoid and leaf charcoals, but that it marginally reduced those of wood.

255 Nevertheless, the aspect ratios for many fuel types overlap, which requires the use of fine anatomical features to improve the utility of the charcoal morphologies in fuel type identification (see section 4.3)

\subsection{Finer diagnostic features of the charcoal morphologies for fuel type identification}

Results from fine diagnostic features on charcoal particles show that these can be more confidently used to attribute charcoal 260 particles to certain fuel types. Apart from the extremely elongated shape that differentiates graminoid charred particles from all other fuel types, graminoids are further distinguished under both microscope and stereomicroscope by their flat appearance and breakage into thin filaments (Figs. 4a, A2a). Rectangular epidermal cells, reticulate meshes, oval voids of former epidermal stomata are also good diagnostic features of graminoids. The graminoid charcoals produced in this study are most similar to types C4, C6, D1, D2, and D3 described by Mustaphi and Pisaric (2014) and Enache et al. (2006).

265 A distinct feature of woody charcoal is that they are layered with foliated or striated textures and break into many tiny particles when pressured (Figs. 4b, A2b). This is due to the abundance of fibres and xylem, which leads to charcoals splitting at various angles (Vaughan and Nichols, 1995). Additionally, conifer wood charcoal presents distinct rows of open pits in the tracheid walls. Attempts to distinguish between charred trunk and twig particles were less successful, although charred trunk particles 
https://doi.org/10.5194/bg-2021-1

Preprint. Discussion started: 1 February 2021

(C) Author(s) 2021. CC BY 4.0 License.

(c) (i)

are blockier. Foliated charred wood fragments also share appearance with moss and fern stems. These woody charcoals are most similar to types A1, B1, B2, and B3 (Mustaphi and Pisaric, 2014; Enache et al., 2006).

Typical features of charred deciduous leaves are their polygonal shapes with surfaces characterised by void spaces or undulated surfaces (Figs. 4c, A2a). Netted venation is also sometimes visible, mostly with three branches diverging from a node. In contrast, conifer needles are elongated, often show ramification, and can have a wood-like appearance. The deciduous leaf charcoals found here are most similar to morphologies A2, A3, A4, A5, and A46, and conifer needle charcoals to C1, C2, and

275 C3 (Mustaphi and Pisaric, 2014; Enache et al., 2006).

Charred Sphagnum leaves preserve the meshed pattern of fresh plant material. Often, stems contain ramification, likely scars of former leaves (Figs. 4a, A2a). Both Sphagnum and Politrichum charcoals present curvy fragments not seen in other fuel types. However, stems of Sphagnum and Polytrichum can be easily be mistaken for shrub twigs. Burnt Equisetum can resemble graminoid charcoal. Charred moss is similar to morphologies C4 and C7 (Mustaphi and Pisaric, 2014; Enache et al., 2006).

\subsection{Charcoal morphometrics and morphologies as indicators of fire type: applications and recommendations}

The physical and chemical characteristics of fuel are key factors influencing ignition and fire propagation. Major chemical components of fuels are cellulose, hemicellulose, and lignin, and minor ones include terpenes, resins, and minerals (Plana and Pastor, 2014). Fuels rich in cellulose and hemicellulose (i.e., leaves) pyrolyse at a lower and narrow temperature range (200 and $400{ }^{\circ} \mathrm{C}$ ), whereas those rich in lignin (i.e., wood) pyrolyse at a higher and over a wider range of temperatures $\left(160-900^{\circ} \mathrm{C}\right.$; Yang et al., 2007). Fuel types rich in terpene and resins (conifer wood, needles, Ericaceae) burn faster and hotter, whereas those rich in mineral components (graminoids) burn cooler $\left(200^{\circ} \mathrm{C}\right)$ and less efficiently (Plana and Pastor, 2014). Fuel arrangements also strongly influences fire propagation: living grasses, shrubs, and trees are arranged vertically, whereas dead woody fuels and litter are mostly oriented horizontally. Continuous horizontal fuel layers favour fire propagation, whereas vertical arrangements allow fires to pass from the understory to the canopy, thus affecting fire severity (Cruz and Alexander, 2010).

Siberian forests burn alternatively as cool surface fuelled by graminoids, forbs, ferns, mosses or as hot, high-intensity surface (burning shrubs) and crown fires (Andreson, 1982). Results from this study suggests that the combined use of morphometric and morphological features and charred mass can help distinguish the predominant fuel source. Knowledge of

295 the fuel source may in turn provide clues on fire type, i.e., the combination of fire intensity (temperature) and severity (effect on vegetation). This has a practical importance for determining the ranges of fire severity and frequency that Siberian boreal tree taxa have tolerated in the past, and helps to evaluate their potential to adapt to new fire regimes in the future. For example, charcoal particles with a higher aspect ratio, typical for graminoids, and dominantly graminoid morphologies that tend to preserve only at a lower temperature, likely indicate a graminoid fuel source, and therefore a cooler, lower-intensity fire (Fig.

300 5). Charred moss, especially Sphagnum, is only preserved at low temperatures and has intermediate aspect ratios; thus, its identification as a fuel source would also point to a cool surface fire. Shorter, bulkier particles likely indicate the increased incidence of leaves (low aspect ratio) or wood (intermediate aspect ratio) as a fuel source, and thus the occurrence of a hotter 
https://doi.org/10.5194/bg-2021-1

Preprint. Discussion started: 1 February 2021

(c) Author(s) 2021. CC BY 4.0 License.

(c) (i)

fire (Figs. 2, 5). Besides, charred wood and leaves are easily distinguished based on their morphological features. However, the morphologies and aspect ratios of leaves of deciduous trees overlap with leaves of shrubs, and those of wood of tree overlap wood of shrub. This makes it hard to disentangle whether such charred particles originated from high-intensity surface fires fuelled by living shrubs and dead wood and leaves, or from high-intensity crown fires that combusted living trees. In such cases, charred mass can offer further information on fire temperature. In the case of hot fires (surface and crown), the present experiments show that shrub leaves are more likely to persist after high-temperature fires than woody biomass. Leaves from shrubs, forbs, and ferns and stems of fern and brown moss are more likely to remain as charred particles after high-temperature

310 fires than graminoids and Sphagnum. The burning experiments also revel that charred particles identified as forbs originate from several fuel types including ferns and brown moss, which tend to have similar morphologies (see section 4.3).

The aspect ratio, dominant morphotypes, and amount of charcoal particles can also help to distinguish the severity of peat burning, i.e., between cold peat fire, combusting graminoids, and moss, and hot fires additionally combusting shrubs. Correct identification of the type of peat burning is a key to evaluate the consequences of burning intensity on peat plant 315 composition and carbon (C) stock. High fire intensity leads to deeper peat burns, which may trigger shifts in plant composition, and results in augmented $\mathrm{C}$ loss. As most of the species used in this study are common to Northern Hemisphere forests and peatlands, results can be directly applicable over a broad geographical scale.

The consistency of results from this study with some of those found in the literature on other vegetation types (boreal forest, temperate and tropical woodlands, and grasslands, see 4.1 and 4.2) suggests the applicability of charcoal aspect ratio and morphologies to a wider variety of vegetation types. For example, the expansion of open habitats (opening up of the forests, expansion of forest steppe and grasslands and latitudinal treeline, or depression of elevational treeline) and increased availability of herbaceous biomass and fuel burnt may be reflected in an increase in aspect ratio and graminoid morphologies. Conversely, the closing up of the forests or tundra shrub encroachment may show itself in a decreased aspect ratio of particles and increased bulky morphologies derived from leaves and wood. The insights gained by these experiments can be used to 325 determine the role of palaeofires in the ecological and evolutionary processes. Further investigations are, however, necessary to relate the proportion of particular charcoal morphotypes or groups of morphotypes (woody vs. graminoid) to the quantity of biomass. These experiments should also clarify the link the between chemical composition of fuels, combustions temperature and charcoal production. In all instances, additional information on ecosystem composition and structure derived from pollen and plant macrofossils can greatly complement and exchange the usefulness of charcoal morphologies for the 330 interpretation of palaeofires.

\section{Conclusions}

This study presents the first results of the morphometric aspects and finer diagnostic features of charred particles produced in the laboratory from seven fuel types comprising 17 plant species from boreal Siberia. The use of a higher number of fuel types 335 from species with broad geographical coverage combined with an exploration of various combustion temperatures improves the link between charcoal morphologies, fuel types, and fire characteristics. 
https://doi.org/10.5194/bg-2021-1

Preprint. Discussion started: 1 February 2021

(C) Author(s) 2021. CC BY 4.0 License.

(c) (i)

In terms of charred mass production, results from this study show that graminoid, Sphagnum, and trunk wood lose their charred mass at lower temperatures than leaves of heathland shrub, brown moss, and fern. The distinct effect of temperature on fuel types suggests that species with low mass retention during hotter fires are likely to be underrepresented in the fossil

340 charcoal record.

Among the three charcoal morphometrics measured (length, aspect ratio, and surface area), the aspect ratio appeared to be the strongest indicator of fuel type. Graminoid charred particles are more elongate than all other fuel types, leaves are the shortest and bulkiest, and twigs and wood are intermediate. The use of fine diagnostic features was more successful in separating wood, graminoids, and leaves. However, it is hard to make further distinctions within these fuel types, especially between tree and

345 shrub wood and between deciduous trees, shrubs, and fern leaves.

The charcoal morphologies and metrics can be used to infer changes in fire temperature (intensity) and impact on vegetation (severity). High-aspect-ratio particles, typical of graminoids, and the dominance of morphotypes derived from surface fuels (graminoids, Sphagnum) could indicate cool, surface fires, whereas lower-aspect-ratio particles and the increased abundance of wood and leaf morphologies may indicate hotter fires. However, the morphologies and aspect ratios of leaves of deciduous trees overlap with leaves of shrubs, and those of wood of tree overlap wood of shrub. This makes it hard to disentangle whether such charred particles originated from high-intensity surface fires fuelled by living shrubs and dead wood and leaves, or from high-intensity crown fires that combusted living trees.

Despite these limitations, the combined use of particle aspect ratio and charred morphotypes allows more robust interpretations of changes in fuel source and fire type based on charcoal records. This can substantially refine histories of past wildfires. Future efforts to determine fuel sources based on analyses of small charcoal fragments will require a more detailed examination of plant anatomy. The use of image-recognition software to collect data on other features may improve estimations of fire temperature.

Data sets: A limited amount of burnt plant material can be made available upon request.

360 Author contribution: AF designed the burning experiments and carried them out. AF performed the morphometrical and morphological analyses; AF performed numerical analysis and data presentation; AF wrote the manuscript; AF acquired the financial support for the project leading to this publication.

Competing interests: The author declare that they have no conflict of interest.

Special issue statement: The role of fire in the Earth system: understanding interactions with the land, atmosphere, and 365 society (ESD/ACP/BG/GMD/NHESS inter-journal SI)

Acknowledgements I would like to thank Markus Rosensthil for the help to develop the code for automatic detection of charred particles and drawing the pictograms in Fig 5; Dagmar Fritzsch for initial brainstorming on the burning experiments; 
https://doi.org/10.5194/bg-2021-1

Preprint. Discussion started: 1 February 2021

(C) Author(s) 2021. CC BY 4.0 License.

(c) (i)

Doris Schneider for help with burning plant material in muffle oven; and Sergey Kirpotin for help with identification of plant species in field.

Financial support: This work was supported from the Deutche Forschungsgemeinschaft grant number FE_1096/6.

\section{References}

Anderson, R.C.: The eastern prairie-forest transition - an overview. In Ballard, H.E. Jr., Brewer, L.S. and Fox, C., editors, 375 Proceedings of the eighth North American Prairie Conference, Kalamazoo, Michigan: Western Michigan University, 86$92,1992$.

Aleman, J.C., Blarquez, O., Bentaleb, I. et al.: Tracking landcover changes with sedimentary charcoal in the Afrotropics. The Holocene, 23, 1853-1862, https://doi.org/10.1177/0959683613508159, 2013.

Clark, J.S., Lynch, J., Stocks, J.B. and Goldhammer, J.: Relationship between charcoal particles in air and sediments in west central Siberia. The Holocene 9, 19-29. https://doi.org/10.1191/095968398672501165, 1998.

Courtney-Mustaphi, C.J., Pisaric, M.F.: A classification for macroscopic charcoal morphologies found in Holocene lacustrine sediments. Progress in Physical Geography 38, 734-754. https://doi.org/10.1177/0309133314548886, 2014.

Crawford, A.J., Belcher, C.M.: Charcoal morphometry for paleoecological analysis: the effects of fuel type and transportation on morphological parameters. Applications in Plant Sciences, 2, 1400004. https://doi.org/10.3732/apps.1400004, 2014.

385 Daniau, A.-L., Goñi, M.F.S., Martinez, P., Urrego, D.H.V., Bout-Roumazeilles, V., Desprat, S., Marlon, J.R.: Orbital-scale climate forcing of grassland burning in southern Africa. Proceedings of the National Academy of Sciences, USA 110, 5069- 5073. https://doi.org/10.1073/pnas.1214292110, 2013.

Enache, M.D., Cumming, B.F.: Tracking recorded fires using charcoal morphology from the sedimentary sequence of Prosser Lake, British Columbia (Canada). Quat Res. 65, 282-292. https://doi.org/10.1016/j.yqres.2005.09.003, 2006.

Enache, M.D., Cumming, B.F.: Charcoal morphotypes in lake sediments from British Columbia (Canada): an assessment of their utility for the reconstruction of past fire and precipitation. J. Paleolimnol. 38, $347-363$. https://doi.org/10.1007/s10933-006-9084-8, 2007.

Feurdean, A., Veski, S., Florescu, G., Vannière, B., Pfeiffer, M., O'Hara, R.B., Stivrins, N., Amon, L., Heinsalu, A., Vassiljev, J. and Hickler, T.: Broadleaf deciduous forest counterbalanced the direct effect of climate on Holocene fire regime in hemiboreal/boreal region (NE Europe). Quaternary Science Reviews, 169, 378-390. https://doi.org/10.1016/j.quascirev.2017.05.024, 2017.

Feurdean, A. and Vasiliev, I.: The contribution of fire to the late Miocene spread of grasslands in eastern Eurasia (Black Sea region). Scientific reports, 9, 1-7. https://doi.org/10.1038/s41598-019-43094-w, 2019a. 
https://doi.org/10.5194/bg-2021-1

Preprint. Discussion started: 1 February 2021

(c) Author(s) 2021. CC BY 4.0 License.

\section{(c) (1)}

Feurdean, A., Tonkov, S., Pfeiffer, M., Panait, A., Warren, D., Vannière, B., Marinova, M.: Fire frequency and intensity associated with functional traits of dominant forest type in the Balkans during the Holocene. European Journal of Forest Research 138, 1049-1066. https://doi.org/10.1007/s10342-019-01223-0, 2019b.

Feurdean, A., Florescu, G., Tanţău, I., Vannière, B., Diaconu, A.C., Pfeiffer, M., Warren, D., Hutchinson, S.M., Gorina, N., Gałka, M. and Kirpotin, S.: 2020. Recent fire regime in the southern boreal forests of western Siberia is unprecedented in the last five millennia. Quaternary Science Reviews, 244, 106495. https://doi.org/10.1016/j.quascirev.2020.106495, 2020.

405 Furyaev, V.V.: Role of fire in forest development. Nauka Publications: Novosibirsk)[In Russia, 1996).

Hawthorne, D., Mustaphi, C.J.C., Aleman, J.C., Blarquez, O., Colombaroli, D., Daniau, A.L., Marlon, J.R., Power, M., Vanniere, B., Han, Y. and Hantson, S., (GMCD).: A tool for exploring proxy-fire linkages and spatial patterns of biomass burning. Quaternary International, 488, 3-17. https://doi.org/10.1016/j.quaint.2017.03.046, 2018.

Hudspith, V.A., Hadden, R.M., Bartlett, A.I. and Belcher, C.M.: Does fuel type influence the amount of charcoal produced in wildfires? Implications for the fossil record. Palaeontology, 61, 159-171. https://doi.org/10.1111/pala.12341, 2018.

Jensen, K., Lynch, E., Calcote, R., Hotchkiss, S.C.: Interpretation of charcoal morphotypes in sediments from Ferry Lake, Wisconsin, USA: do different plant fuel sources produce distinctive charcoal morphotypes? Holocene 17, 907-915. https://doi.org/10.1177/0959683607082405, 2007.

Jones, M.W., Smith, A., Betts, R., Canadel, J.G., 1, Prentice, I.C., Le Quéré, C.: Climate change increases the risk of wildfires. 415 https://sciencebrief.org/briefs/wildfires, 2020.

Marlon, J. R., Kelly, R., Daniau, A.-L., Vannière, B., Power, M. J., Bartlein, P., Higuera, P., Blarquez, O., Brewer, S., Brücher, T., Feurdean, A., Romera, G. G., Iglesias, V., Maezumi, S. Y., Magi, B., Courtney Mustaphi, C. J., and Zhihai, T.: Reconstructions of biomass burning from sediment-charcoal records to improve data-model comparisons, Biogeosciences, 13, 3225-3244. https://doi.org/10.5194/bg-13-3225-2016, 2016.

420 Moritz, M.A., Batllori, E., Bradstock, R.A., Gill, A.M., Handmer, J., Hessburg, P.F., Leonard, J., McCaffrey, S., Odion, D.C., Schoennagel, T., Syphard, A.D:. Learning to coexist with wildfire. Nature 515, 58-66. https://doi.org/10.1038/nature13946, 2014.

MacDonald, G.M., Larsen, C.P.S., Szeicz, J.M. and Moser, K.A.: The reconstruction of boreal forest fire history from lake sediments: a comparison of charcoal, pollen, sedimentological, and geochemical indices .Quaternary Science Reviews 10, 53-71 . https://doi.org/10.1016/0277-3791(91)90030-X, 1991.

Orvis, K.H., Lane, C.S., Horn, S.P.: Laboratory production of vouchered reference charcoal from small wood samples and non-woody plant tissues. Palynology 29, 1-11. https://www.jstor.org/stable/3687800, 2005.

Pereboom, E.M., Vachula, R.S., Huang, Y., Russell, J.: The morphology of experimentally produced charcoal distinguishes fuel types in the Arctic tundra. The Holocene, 7, 1-6. https://doi.org/10.1177/0959683620908629, 2020.

430 Planas, E., Pastor, E.: Wildfire behaviour and danger rating. In: Belcher, C., editor, Fire phenomena and the Earth system: an interdisciplinary guide to fire science, 53-76. doi:10.1002/9781118529539, John Wiley \& Sons, Ltd, 2014. 
https://doi.org/10.5194/bg-2021-1

Preprint. Discussion started: 1 February 2021

(C) Author(s) 2021. CC BY 4.0 License.

(c) (i)

Rein, G.: Smoldering fire and natural hazard. In: Belcher, C., editor, Fire phenomena and the Earth system: an interdisciplinary guide to fire science,15-34. doi:10.1002/9781118529539, John Wiley \& Sons, Ltd, 2014.

Scott, A.C.: Charcoal recognition, taphonomy and uses in palaeoenvironmental analysis. Palaeogeography, Palaeoclimatology, Palaeoecology, 291, 11-39. https://doi.org/10.1016/j.palaeo.2009.12.012, 2010.

Umbanhowar, C.E, McGrath, M.J.: Experimental production and analysis of microscopic charcoal from wood, leaves and grasses. The Holocene, 8, 341-346. https://doi.org/10.1191/095968398666496051, 1998.

Unkelbach, J., Dulamsuren, C., Punsalpaamuu, G., Saindovdon, D., Behling, H.: Late Holocene vegetation, climate, human and fire history of the forest-steppe-ecosystem inferred from core G2-A in the 'Altai Tavan Bogd' conservation area in Mongolia. Veget Hist Archaebot, 27, 665-677 DOI: 10.1007/s00334-017-0664-5, 2018.

Vaughan, A., Nichols, G.: Controls on the deposition of charcoal: implications for sedimentary accumulations of fusain. Journal of Sedimentary Research A65, 130-135. https://doi.org/10.1306/D426804A-2B26-11D7-8648000102C1865D, 1995.

Walsh, M.K., Whitlock, C., Bartlein, P.J.: A 14,300- year-long record of fire-vegetation-climate linkages at Battle Ground Lake, southwestern Washington. Quaternary Research 70: 251-264. https://doi.org/10.1016/j.yqres.2008.05.002, 2008.

Walsh, P.M. and Li, T.: Fragmentation and attrition of coal char particles undergoing collisions during combustion at temperatures from 900-1100 K . Combustion and Flame 99, 749-757 . https://doi.org/10.1016/0010-2180(94)90070-1, 1994.

Ward, D.E. and Hardy, C.C.: Smoke emissions from wildland fires. Environment International 17, 117-134, 1991.

Whitlock, C., Larsen, C.: Charcoal as a fire proxy. In Smol, JP, Birks, HJB and Last, WM., editors, Tracking environmental change using lake sediments. Volume 3: terrestrial, algal, and siliceous indicators. Kluwer Academic Publishers, 75-97, 10.1007/0-306-47668-1, https://doi.org/10.1007/0-306-47668-1_5, 2002.

Yang, H., Yan, R., Chen, H., Lee, D. H. and Zheng, C.: Characteristics of hemicellulose, cellulose and lignin pyrolysis. Fuel, 86, 1781- 1788. https://doi.org/10.1016/j.fuel.2006.12.013. 2007

Figure legends and embedded figures 
https://doi.org/10.5194/bg-2021-1

Preprint. Discussion started: 1 February 2021

(c) Author(s) 2021. CC BY 4.0 License.

\section{(c) (1)}

Figure 1. The percent of charred mass retained after burning known plant species from Siberia in a muffle oven at 250, 300, 350, and $400{ }^{\circ} \mathrm{C}$. Abbreviations: L, leaf; $\mathrm{N}$, needles; $\mathrm{t}$, twig; w, wood. The median mass retained for similar fuel types 470 (identified by the same colour) are reported as black diamonds.
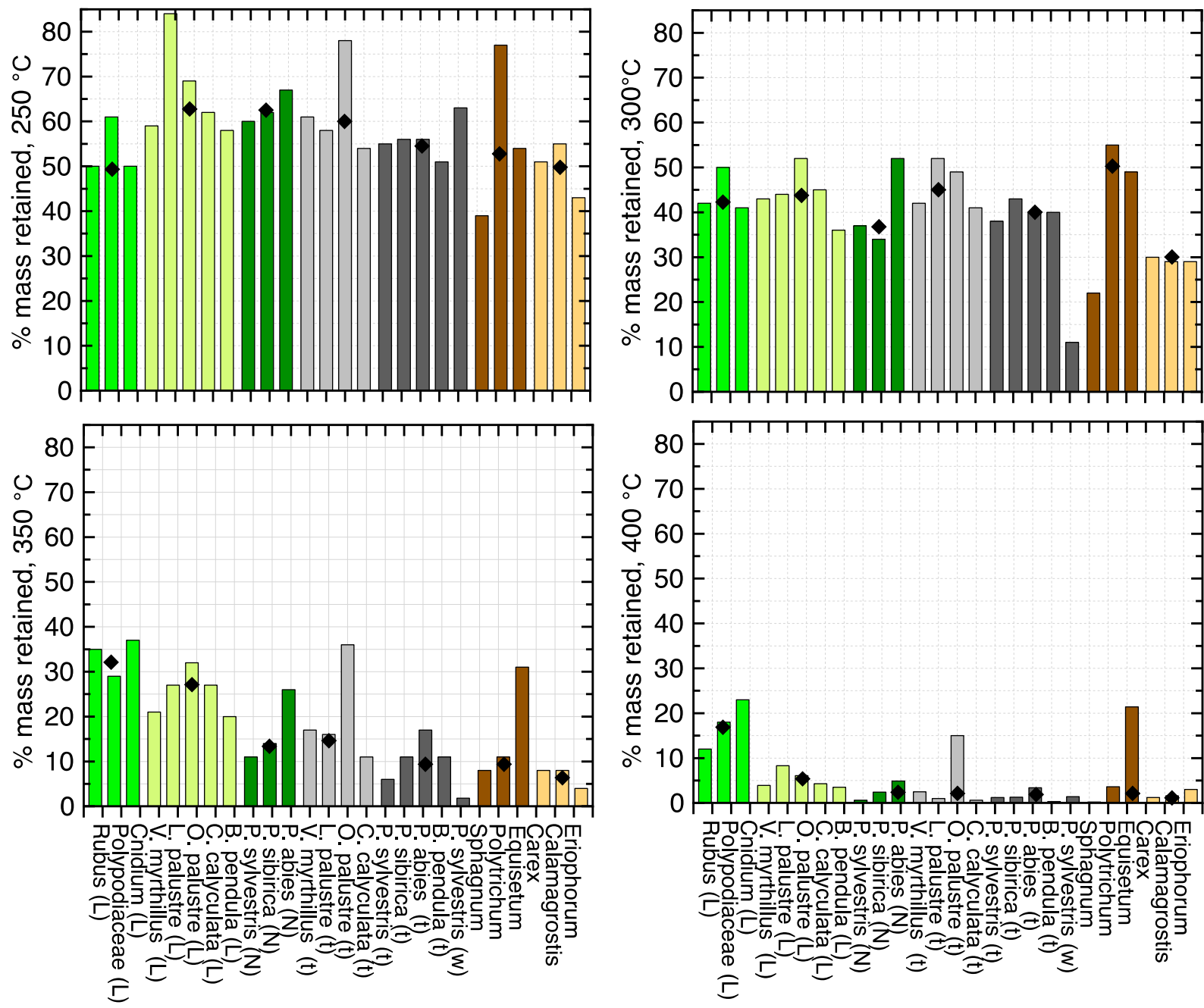

\footnotetext{
$\square$ Leaf (forb) $\square$ Leaf (broadleaf tree and shrub)
} 
https://doi.org/10.5194/bg-2021-1

Preprint. Discussion started: 1 February 2021

(c) Author(s) 2021. CC BY 4.0 License.

475 Figure 2. The median aspect ratios of charred particles from (a-d) individual taxa burned at $250,300,350$, and $400{ }^{\circ} \mathrm{C}$, respectively, and (e-g) fuel types at burning temperatures of 250,300 , and $350{ }^{\circ} \mathrm{C}$, respectively, as well as from (h) mixedfuel samples burned at $300{ }^{\circ} \mathrm{C}$. The fuel mixtures are arranged in order of increasing proportions of graminoids. Box plots represent the distribution of data as follows: the horizontal line in each box denotes the median, the upper quartile is the median value of the upper half of the data points, the lower quartile is the median value of the lower half of the data points, whiskers represent the minimum and the maximum values. Abbreviations of plant material burned are given in Figure 1. The individual taxa belonging (a-c) to a fuel-type group $(\mathrm{d}-\mathrm{g})$ are indicated by the same color.
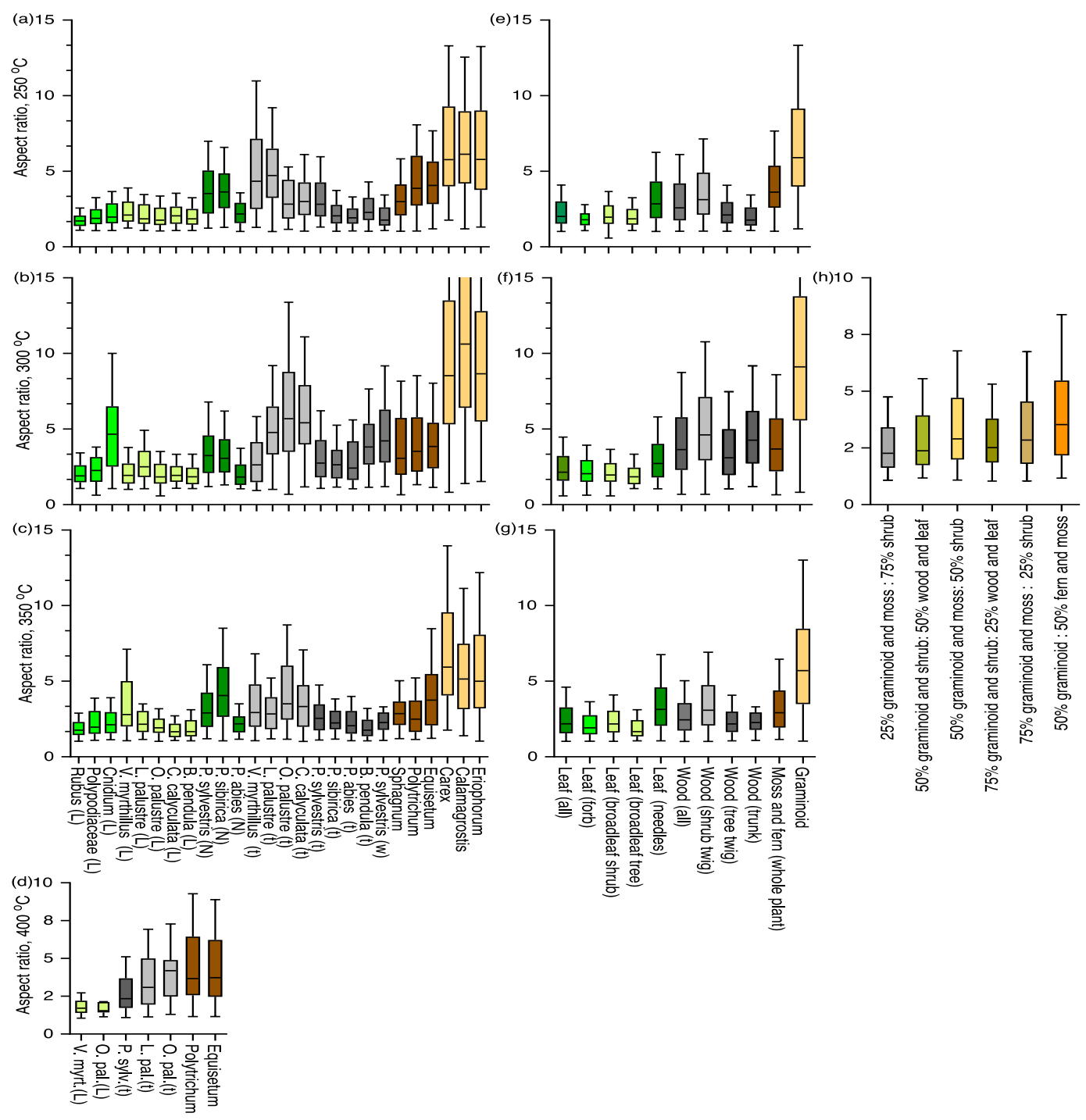
https://doi.org/10.5194/bg-2021-1

Preprint. Discussion started: 1 February 2021

(c) Author(s) 2021. CC BY 4.0 License.

Figure 3. The median lengths $(\mu \mathrm{m})$ and surface areas $\left(\mu \mathrm{m}^{2}\right)$ of charred particles from $(\mathrm{a}, \mathrm{b})$ individual taxa, $(\mathrm{c}, \mathrm{d})$ fuel types, and (e, f) fuel mixtures at $300{ }^{\circ} \mathrm{C}$. Abbreviations as in Figure 1. See Figure 2 for description of box plots and colour coding.
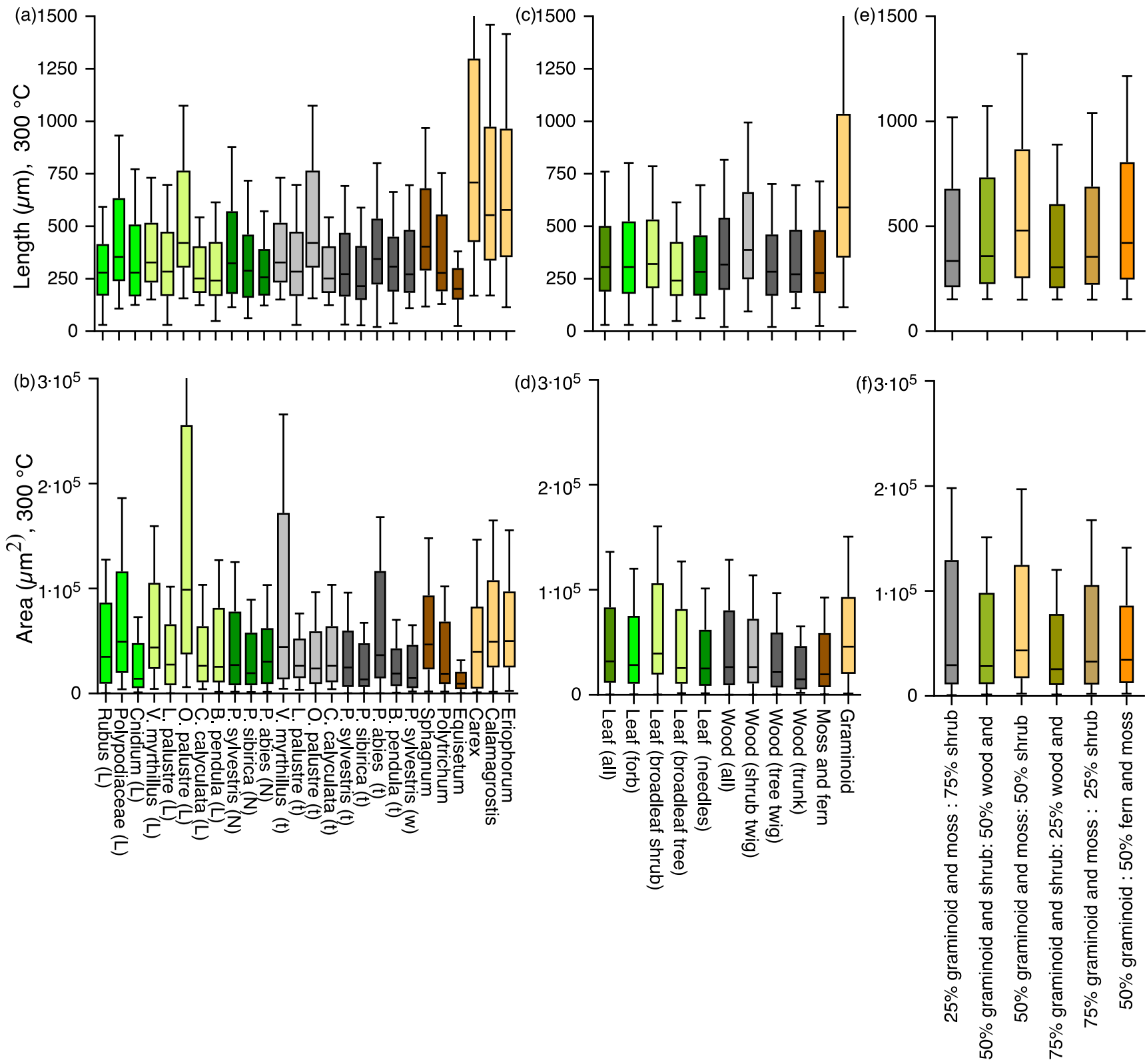
https://doi.org/10.5194/bg-2021-1

Preprint. Discussion started: 1 February 2021

(c) Author(s) 2021. CC BY 4.0 License.

(c) (i)

495 Figure 4. Photomicrographs of characteristic charcoal morphotypes under stereomicroscope $(4 \times)$. (a) Graminoids (1-10), ferns (11-13), and moss (14-18). (b) Wood from tree twigs (1-9), shrub twigs (10-15), and trunks (16-20). (c) Conifer needles (1-6), deciduous tree leaves (7-9), shrub leaves (10-15), fern leaves (16-18), and moss leaves (19-20).

(a)

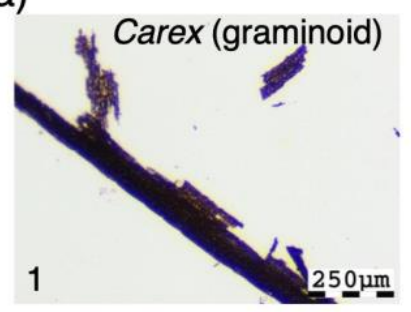

Calamagrostis (graminoid)
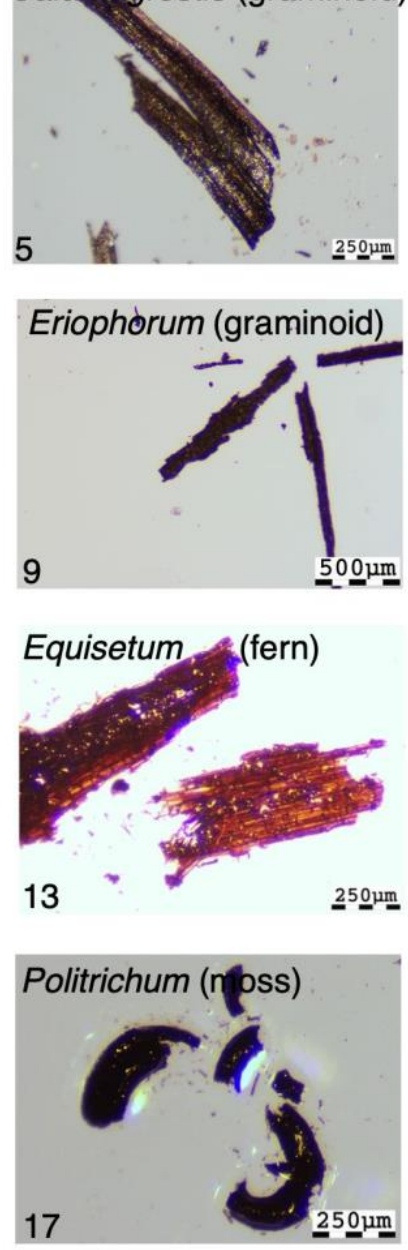
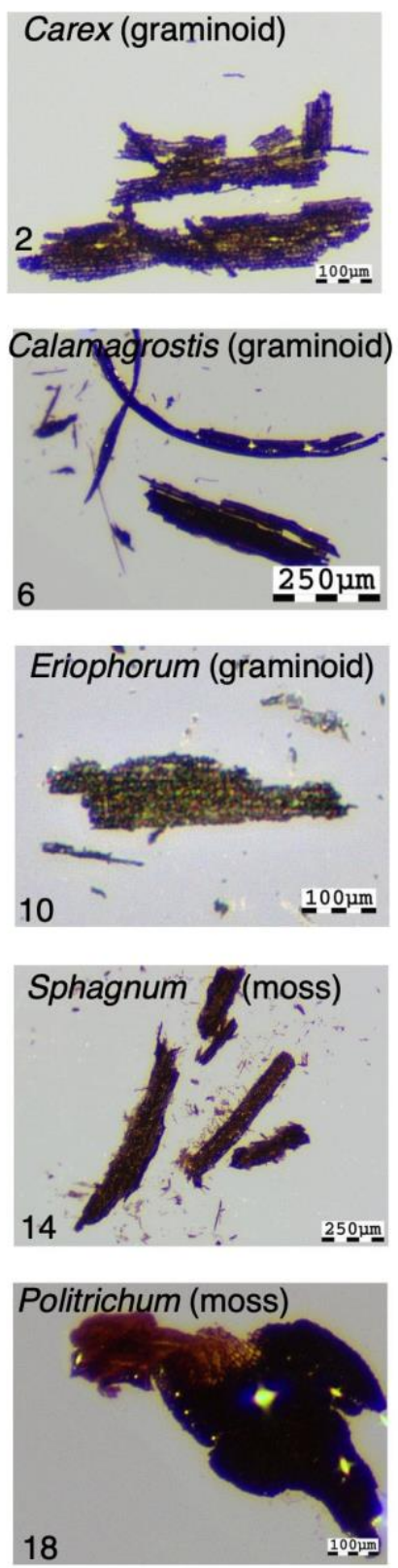
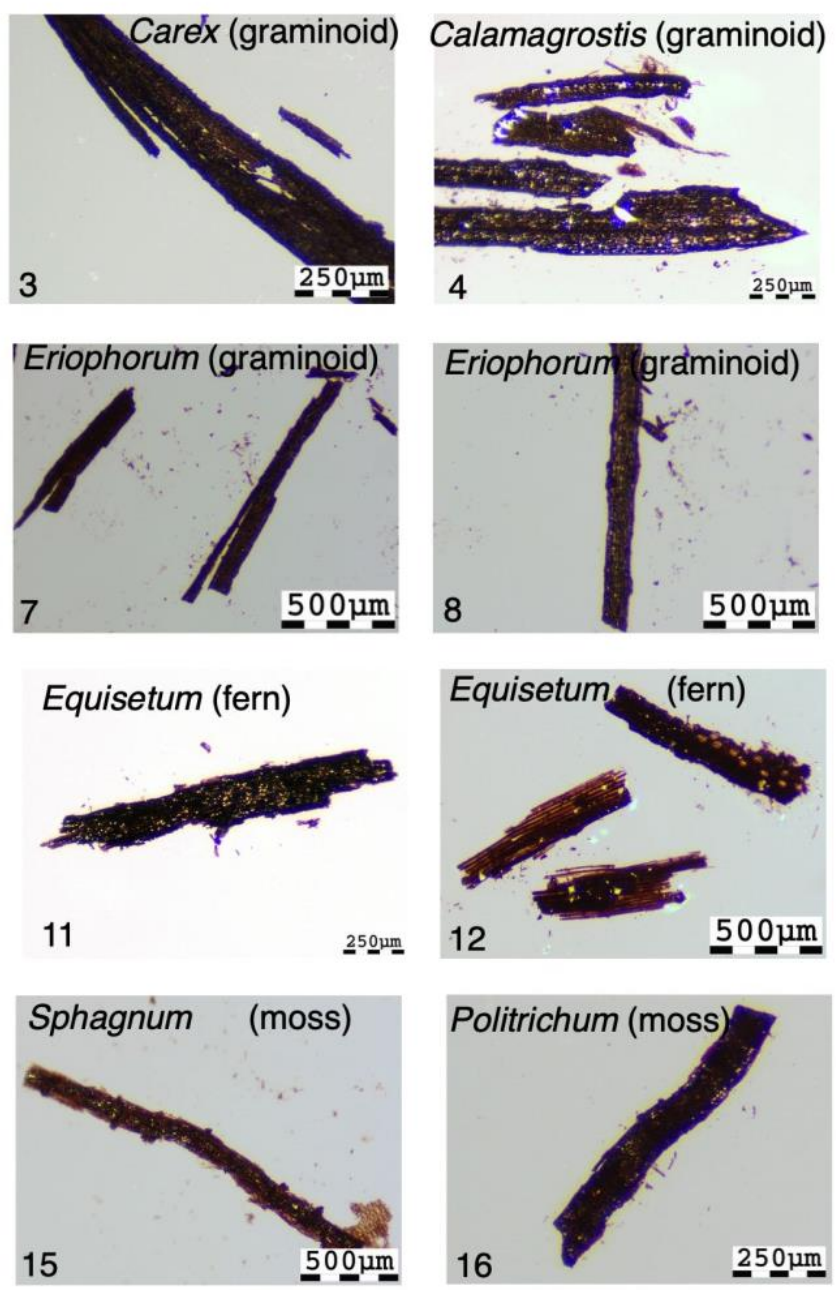
https://doi.org/10.5194/bg-2021-1

Preprint. Discussion started: 1 February 2021

(c) Author(s) 2021. CC BY 4.0 License.

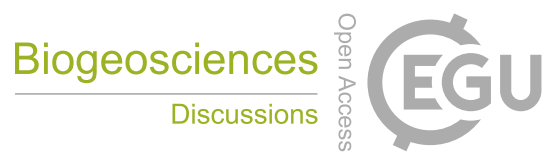

(b)
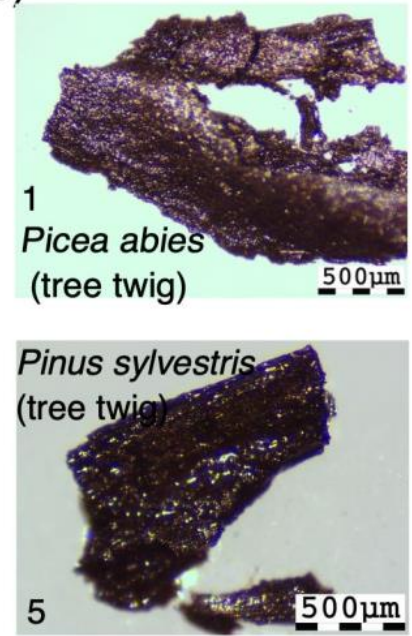

Betula (tree twig)
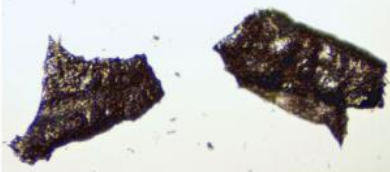

9

$\underline{50} \underline{0} \mu \underline{m}$
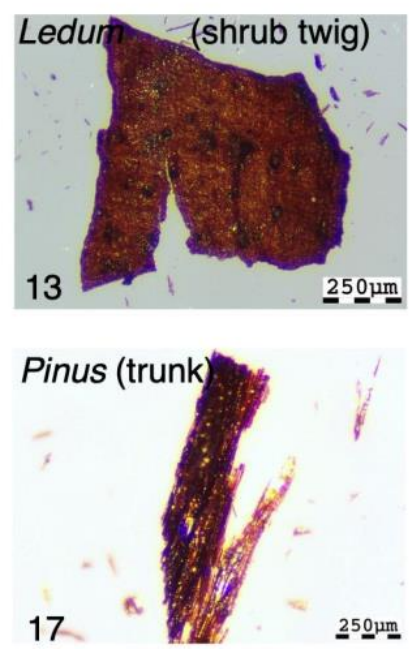

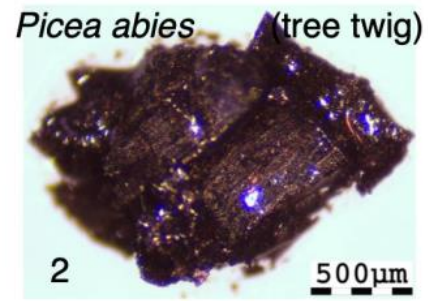

Pinus sylvestris (tree twig)
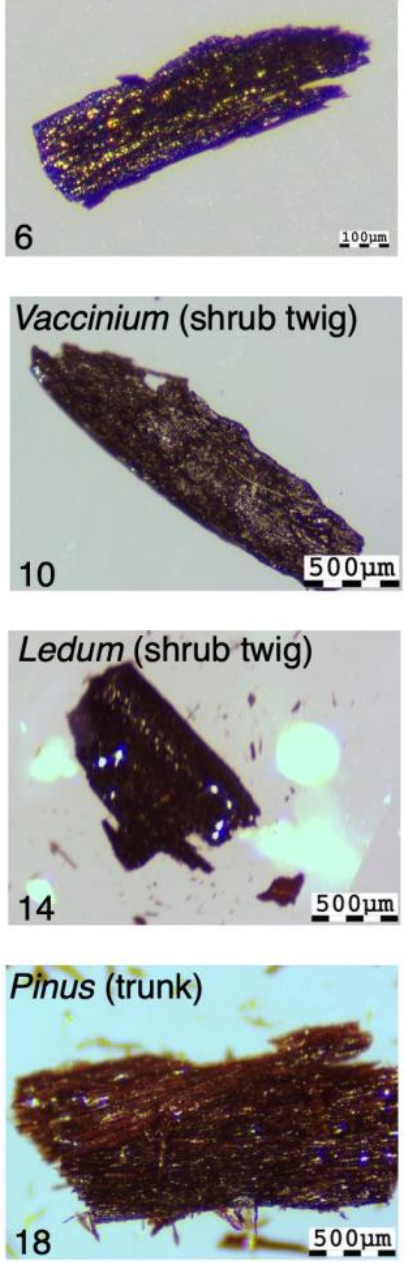
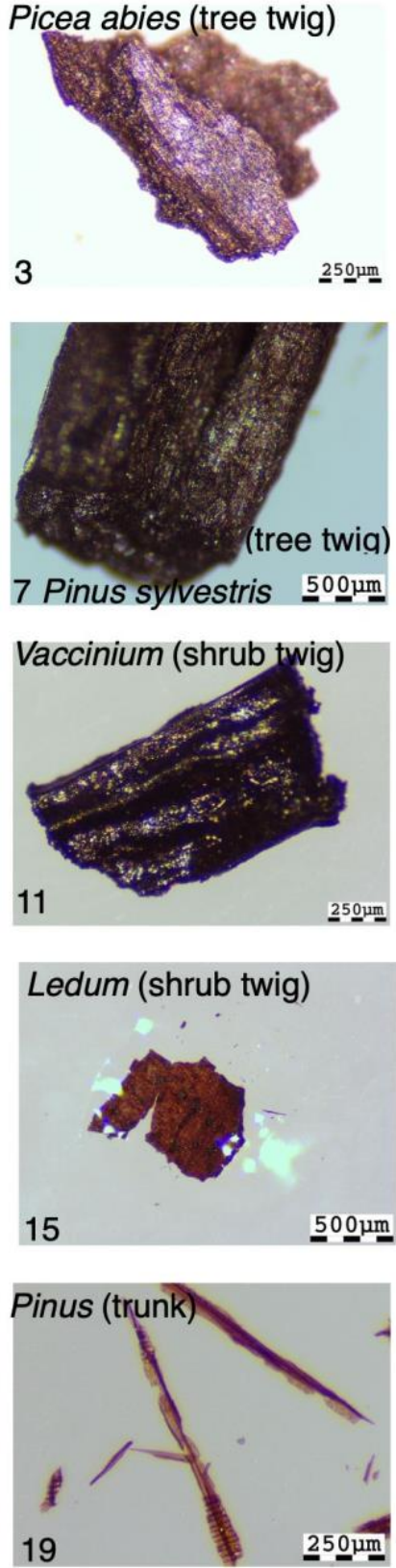

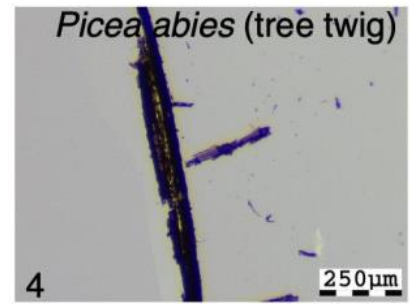

Betula (tree twig)
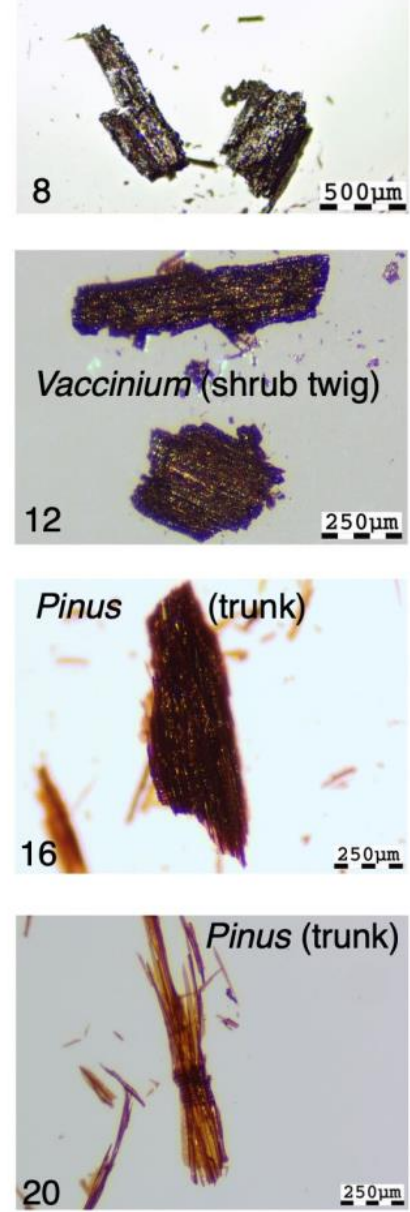
https://doi.org/10.5194/bg-2021-1

Preprint. Discussion started: 1 February 2021

(c) Author(s) 2021. CC BY 4.0 License.
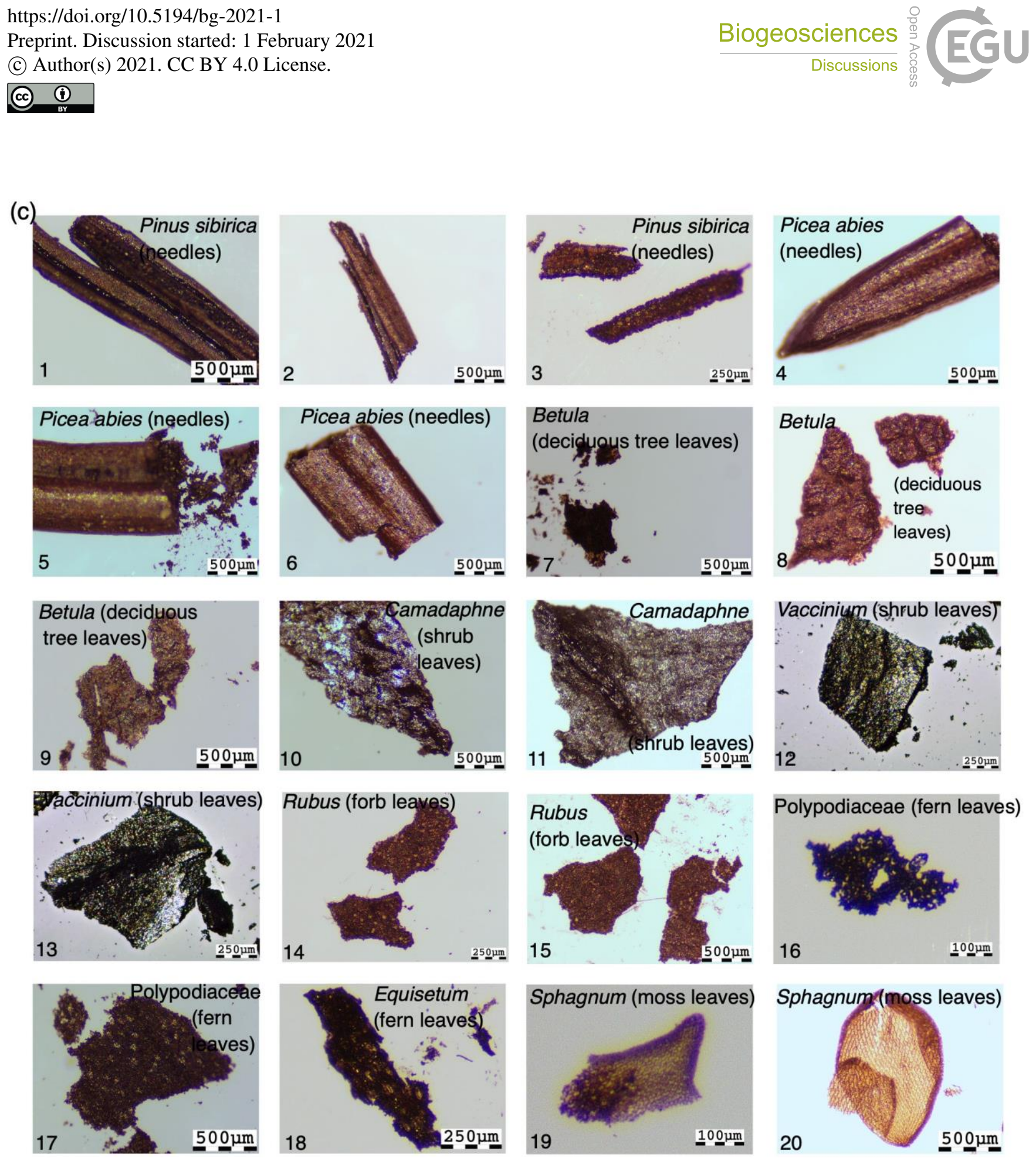
https://doi.org/10.5194/bg-2021-1

Preprint. Discussion started: 1 February 2021

(c) Author(s) 2021. CC BY 4.0 License.

Figure 5. Schematic representation of fire types and the potential link with a fuel types burnt and predominant charcoal morphometrics (aspect ratio) and morphologies as well as charcoal production.

Fire type

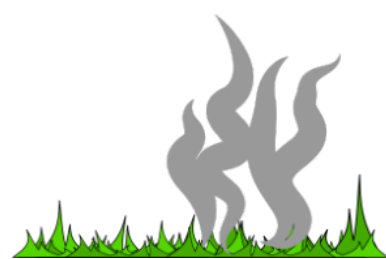

Surface cool fire

Graminoids (grass, sedge)

Fuel type Moss (i.e. Sphagnum)

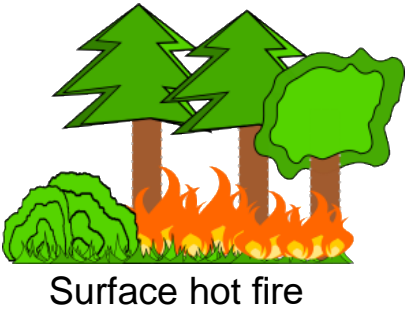

Ferns (i.e. Equisetum)

Live \& dead shrub leaves and wood Dead tree leaves and wood

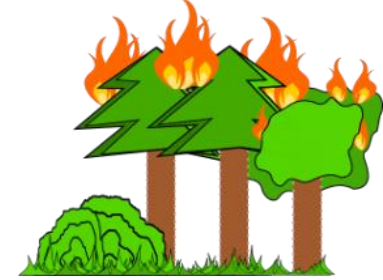

Crown hot fire

\section{Chacoal production}

Aspect ratio

Morphologies
Low

High

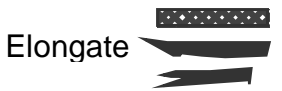

High

Intermediate

Polygonal \& Rectangular

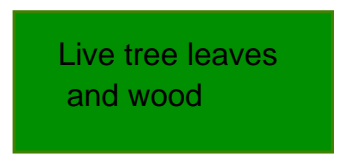

Intermediate

Low to intermediate

Polygonal \& Rectangular 
https://doi.org/10.5194/bg-2021-1

Preprint. Discussion started: 1 February 2021

(c) Author(s) 2021. CC BY 4.0 License.

Tables

Table 1. List of plant materials burned. All plants are from Siberia, Russia, except Picea abies, originating from Taunus,

530 Germany.

\begin{tabular}{|c|c|c|c|c|c|}
\hline & Plant type & Scientific name & Family & Common name & Plant burned \\
\hline \multirow{5}{*}{535} & Trees & & & & \\
\hline & Conifer tree & Pinus sylvestris & Pinaceae & Scots pine & Needles \\
\hline & Conifer tree & Pinus sylvestris & Pinaceae & Scots pine & Twigs \\
\hline & Conifer tree & Pinus sylvestris & Pinaceae & Scots pine & Dead wood \\
\hline & Conifer tree & Pinus sibirica & Pinaceae & Siberian pine & Needles \\
\hline \multirow{5}{*}{540} & Conifer tree & Pinus sibirica & Pinaceae & Siberian pine & Twigs \\
\hline & Conifer tree & Picea abies & Pinaceae & Norway spruce & Needles \\
\hline & Conifer tree & Picea abies & Pinaceae & Norway spruce & Twigs \\
\hline & Deciduous tree & Betula pendula & Betulaceae & Silver birch & Leaves \\
\hline & Deciduous tree & Betula pendula & Betulaceae & Silver birch & Twigs \\
\hline \multirow{4}{*}{545} & Shrubs & & & & \\
\hline & Shrub & Vaccinium myrtillus & Ericaceae & Bilberry & Leaves \\
\hline & Shrub & Vaccinium myrtillus & Ericaceae & Bilberry & Twigs \\
\hline & Shrub & Oxycoccus palustre & Ericaceae & Bilberry & Leaves \\
\hline \multirow{5}{*}{550} & Shrub & Oxycoccus palustre & Ericaceae & Bilberry & Twigs \\
\hline & Shrub & Empetrum nigrum & Ericaceae & Bilberry & Leaves \\
\hline & Shrub & Empetrum nigrum & Ericaceae & Bilberry & Twigs \\
\hline & Shrub & Ledum palustre & Ericaceae & Bilberry & Leaves \\
\hline & Shrub & Ledum palustre & Ericaceae & Bilberry & Twigs \\
\hline \multirow{3}{*}{555} & Shrub & Chamaedaphne calyculata & Ericaceae & Bilberry & Leaves \\
\hline & Shrub & Chamaedaphne calyculata & Ericaceae & Bilberry & Twigs \\
\hline & Herbaceous & & & & \\
\hline \multirow{8}{*}{560} & Graminoid & Eriophorum vaginatum & Cyperaceae & Cotton grass & Leaves \\
\hline & Graminoid & Calmagrosti. & Poaceae & Reed grass & Leaves \\
\hline & Graminoid & Carex spp. & Cyperaceae & Sedge & Leaves \\
\hline & Forb & Cnidium dubium & Apiaceae & & Leaves \\
\hline & Forb & Rubus spp. & Rosaceae & Raspberry & Leaves \\
\hline & Fern & Polypodium & Polypodiaceae & Fern & Leaves \\
\hline & Fern & Equisetum palustre & Equisetaceae & Horsetail & Stem \\
\hline & Moss & Sphagnum & Sphagnaceae & Peat moss & Stem +leaves \\
\hline 565 & Moss & Polytrichum commune & Polytrichiaceae & Hair moss & Stem +leaves \\
\hline
\end{tabular}

Table 2. Mann-Whitney test for equal medians between fuel types. Significance of p-values $(<0.0001 * * *, 0.001 * *, 0.01 *$ $0.05)$.

Graminoids Wood $\quad$ Leaves $\quad$ Moss and ferns

Aspect ratio $(L: W)$

$250^{\circ} \mathrm{C}$

575 Graminoid

raminoid
rn
ross

0.0001

Leaves $\quad 0.0001$

$-$

$\begin{array}{ll}0.0001 & 0.0001 \\ 0.0001 & 0.0001 \\ - & 0.0001\end{array}$

$300{ }^{\circ} \mathrm{C}$

$580 \quad$ Graminoid

0.0001

0.0001

0.0001

0.0001

Wood

0.0001

0.751 
https://doi.org/10.5194/bg-2021-1

Preprint. Discussion started: 1 February 2021

(c) Author(s) 2021. CC BY 4.0 License.

(c) (1)

Leaves

0.0001

0.0001

0.0001

$350^{\circ} \mathrm{C}$

585 Graminoid

Wood 0.0001

Leaves

0.0001

0.0001

0.0001

0.0002

0.0001

0.0002

$-$

Length (L)

$590 \mathbf{2 5 0}^{\circ} \mathbf{C}$

Graminoid

Wood

- 0.182

Leaves

0.037

0.182
-
0.0001

0.037

0.0687

$0.0001-0.0004$

$\begin{array}{ll}- & 0.835\end{array}$

$595 \mathbf{3 0 0}^{\circ} \mathrm{C}$

Graminoid

Wood

0.0001

0.0001

0.0001

0.0001

Leaves

0.0001

0.0332

0.0332

0.0131

0.220

$600 \mathbf{3 5 0}^{\circ} \mathbf{C}$

Graminoid

Wood

Leaves

0.909

0.0001

0.909

0.210

0.232

0.085

0.220

0.210

0.874

605 Surface area (A)

$250^{\circ} \mathrm{C}$

Graminoid

Wood

0.0001

Leaves

0.0001

0.0001

0.0001

0.0001

0.0001

0.0001

0.742

$\begin{array}{ll}- & 0.0001\end{array}$

$300{ }^{\circ} \mathrm{C}$

Graminoid

Wood

- 0.004

0.004

0.128

0.0001

Leaves

0.128

0.018

0.018

0.0009

615

$350^{\circ} \mathrm{C}$

Graminoid

- 0.0001

620

$\begin{array}{ll}\text { Wood } & 0.0001\end{array}$

0.0001

0.0001

0.0028

0.0021

0.0001

0.0003

\section{Appendix}

Appendix A. The watershed algorithm used to calculate morphometrics of charred particles.

625 The algorithm for automatic detection of morphometrics is based on functions from the Python module skimage (watershed algorithm). First, the picture is converted to a grey scale. A Sobel gradient of the picture is then calculated, which results in an elevation map. In order to use the watershed algorithm to detect the charcoal particles, a map of markers in the grey picture with grey values higher than 140 was then create. These are the starting points of the watershed region fill algorithm. Finally, any holes in the watershed regions were filled with the help of a binary fill method (Soille and Vincent, 1990). The detected particles were subject to the calculation of morphometrics such as surface area and lengths along the major and minor axis via 
https://doi.org/10.5194/bg-2021-1

Preprint. Discussion started: 1 February 2021

(c) Author(s) 2021. CC BY 4.0 License.

(c) (i)

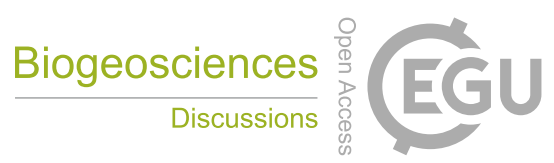

supported functions. Particles with the length of major axis smaller than $150 \mu \mathrm{m}$ were excluded from these calculations. The pixel area has been calibrated with a micrometre scale and the results scaled accordingly.

\section{Reference}

635 Soille, P., Vincent, L. M.: Determining watersheds in digital pictures via flooding simulations. Proc. SPIE 1360: $240-250$. doi:10.1117/12.24211, 1990 .

Appendix B. Photomicrographs of characteristic charcoal morphotypes under microscope (4×). (a) Conifer needles (1-6), deciduous tree leaves (7-8), deciduous shrub leaves (9-11), graminoids (13-15), ferns (16-17), and moss leaves and steams (18-20). (b) Wood from tree twigs (1-6), shrub twigs (7-10), and trunks (11-12. 
(a) (needles) 50은

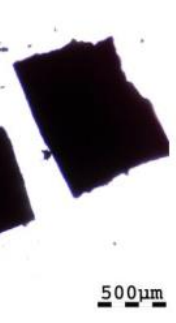
1
Pinús sylvèstris

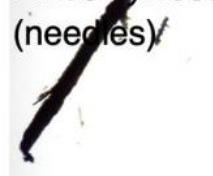

5

Vaccinium (shub leaves).

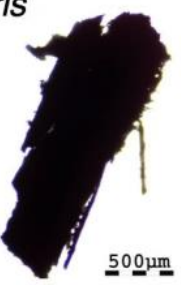

Pinus sylvestris

(needles)

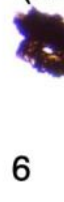

Pinus sibīica

2
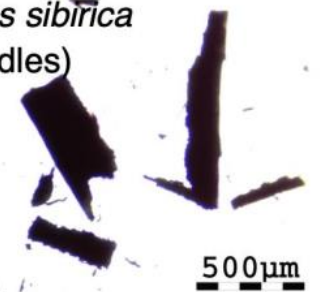

Vaccinium

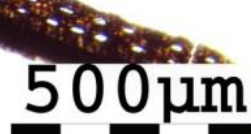

(needles)
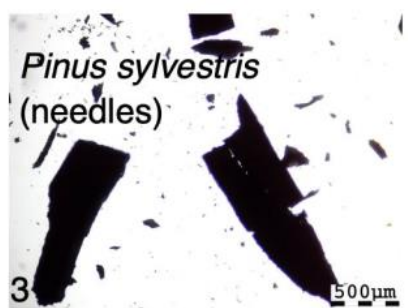

- Betula (deciduous
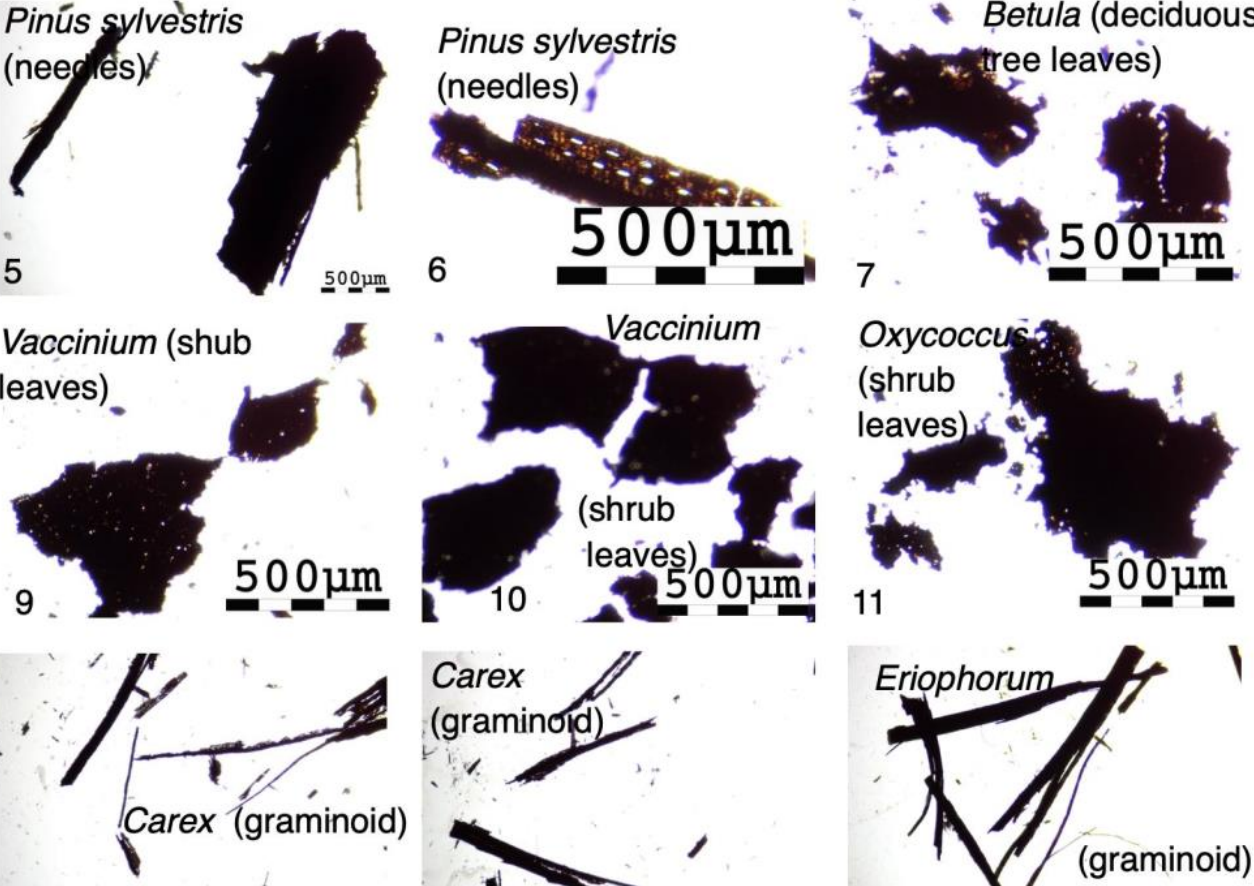

13 50있

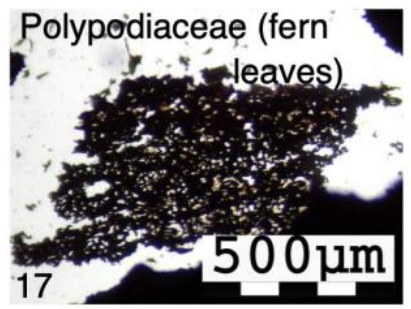

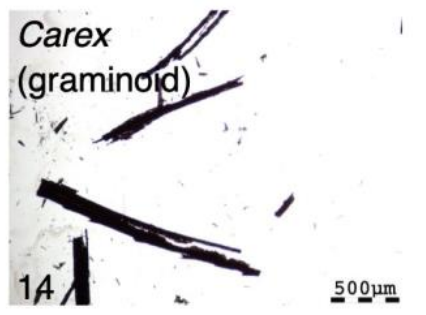

Sphagnum (stems with scars)

18

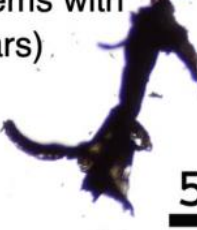

\section{1}
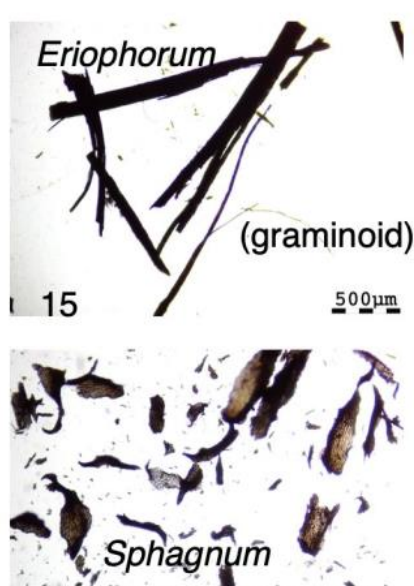

$\lambda_{19}$ (leaves and stemss)
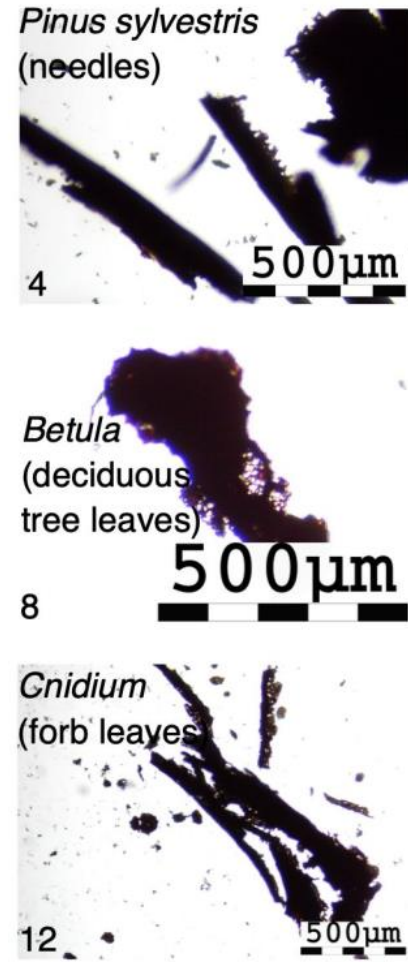

Equisetym (fern)
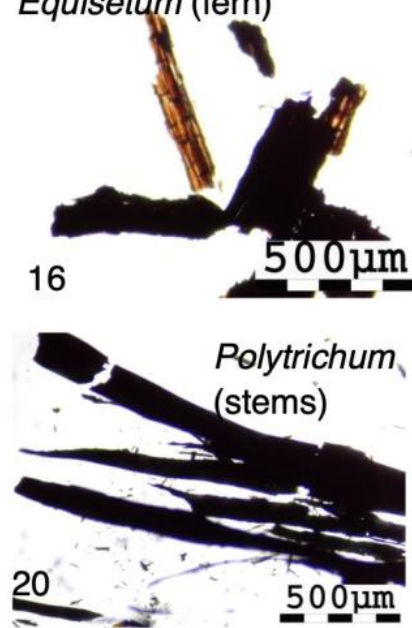
https://doi.org/10.5194/bg-2021-1

Preprint. Discussion started: 1 February 2021

(c) Author(s) 2021. CC BY 4.0 License.

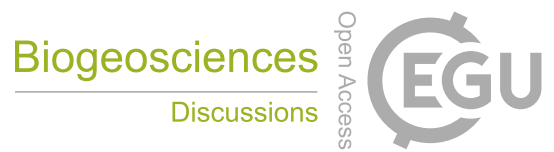

(c) (1)

(b)
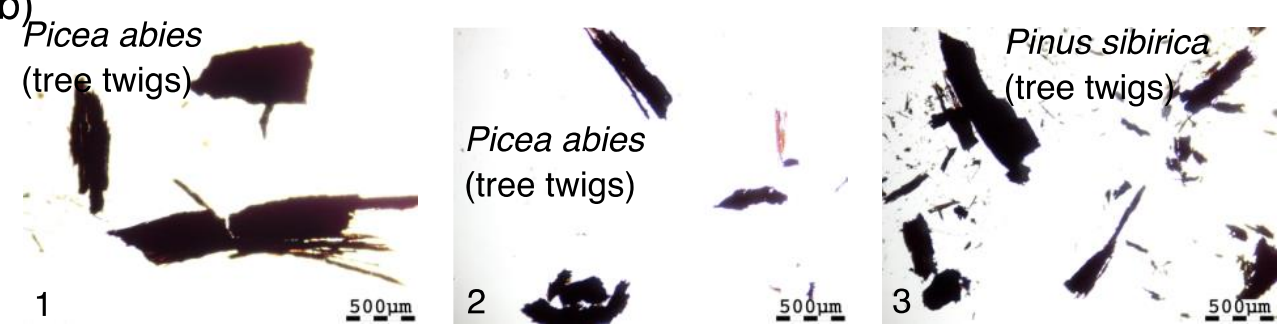

Pinus sibirica

(tree twigs) '
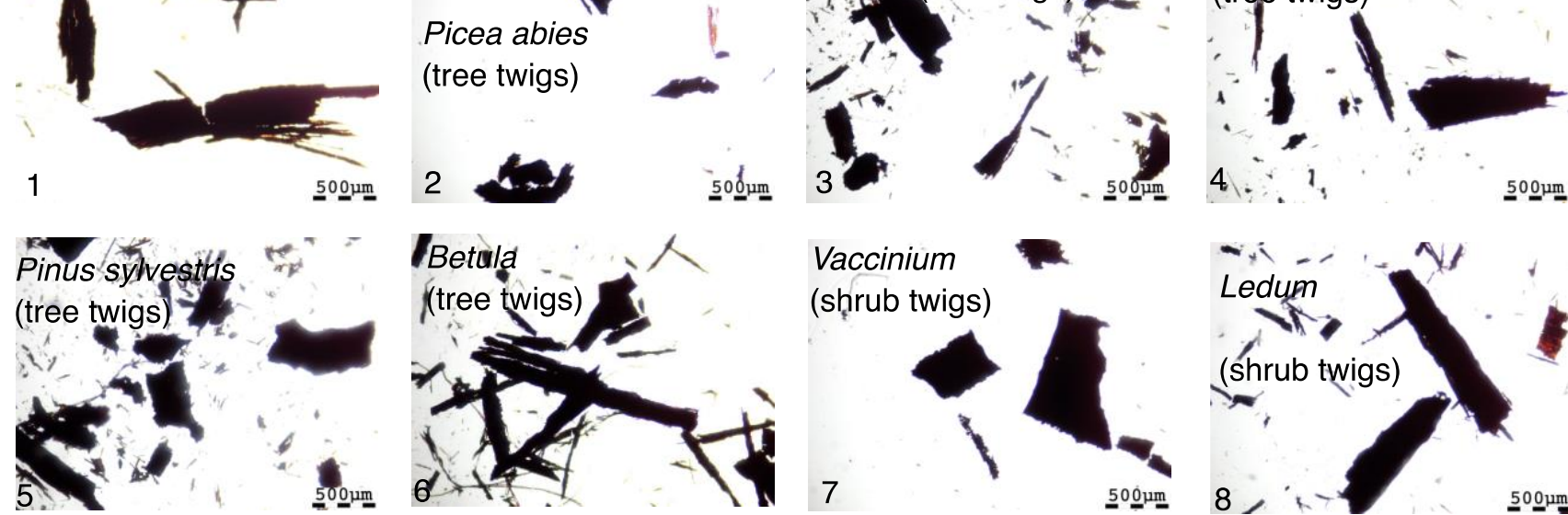

\section{Vaccinium \\ (sh̨rub twigs)}
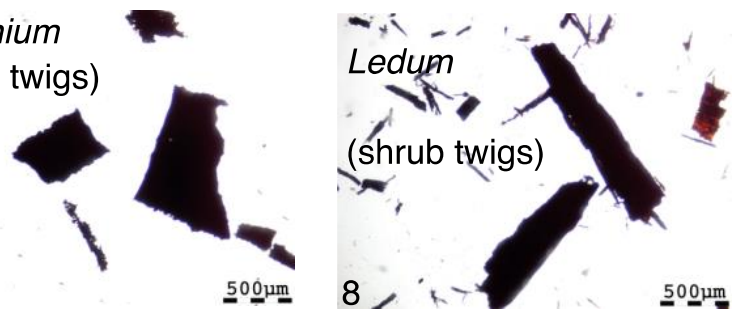

\section{Camadaphne}
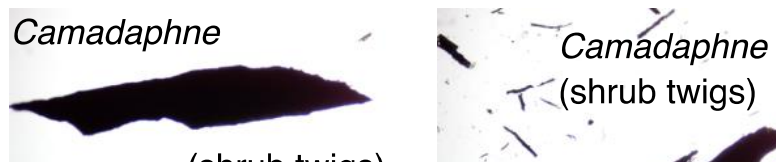

T₹(shrub twigs)

(shrub twigs)

645

50음
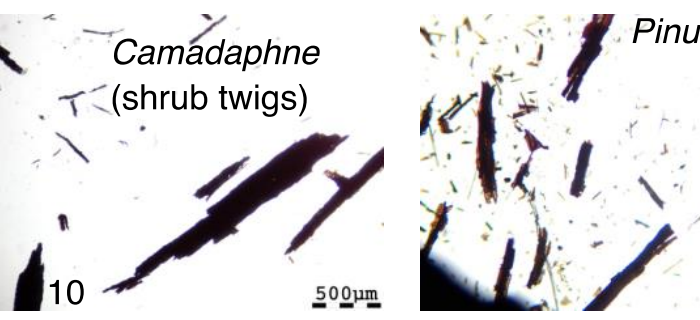

Pinus (trunk)

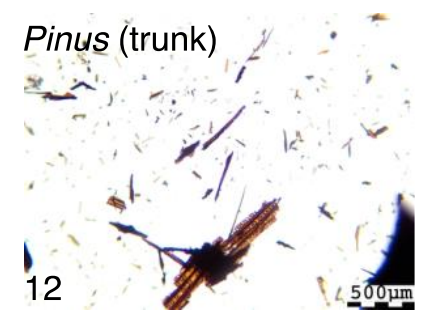

